\title{
ANALISIS KELAYAKAN USAHA MIKRO KECIL DAN MENENGAH (UMKM) SEPATU DAN SANDAL DI BOGOR
}

\author{
Olivia Venessa B. Nainggolan \\ Sekolah Tinggi Ilmu Ekonomi Wiyatamandala \\ olivia.nainggolan@wiyatamandala.ac.id
}

\begin{abstract}
Feasibility Study for Shoes and Sandal Micro Business in Bogor is very important to be conducted. The purpose of this feasibility study is to measure cost and benefit that might be beneficial for every stakeholder especially in rural area. Pasir Eurih Village has been knowned as one of shoes and sandal producer. Long history and many craftman there has been made shoes and sandal for generation. Their knowledge and skill has been passed from generation to generation and create microbusiness and become main economics activity for villager there. Unfortunately there is question that, why such old microbusiness never grow and expand more? In order to answer this question researcher conducted some feasibility study regarding this matter. Researcher wants to search the root of the problem why this microbusiness from Pasir Eurih Village not grow and expand. In this research, researcher conducted feasibility study base on two main aspect of feasibility study. First aspect is non financial aspect of the business which is management, business entities, infrastructure, and some SWOT analysis base on current situation. Second aspect is financial aspect which is NPV, IRR, Profitability Index, and Payback Period. Finding in this research is base on the market, internal competency Pasir Eurih has GOOD feasibility but unfortunately still not manageable with good corporate governance. Lack of leadership and there is no certain business entities that could coordinate this microbusiness cause major delay of its expansion. Researcher purposes that in first step of development, Pasir Eurih could start to organize their internal stakeholder under cooperation business entities (KOPERASI). Pasir Eurih already has KOPERASI but found by researcher failed to be functioned. In order to create competitive product and expand their internal stakeholder need to be trained and develop untuk the best business entities (which is in researcher opinion is KOPERASI). Finally, it is human development that is urgent issued that found by researcher in this topic. Government and some professional business should be together developed rural area in order to achive competitive nation and product.
\end{abstract}

Keywords: Feasibility Study, Small and Micro Business, Shoes and Sandal Business, Pasir Eurih, SWOT Analysis, KOPERASI.

\section{PENDAHULUAN}

Dewasa ini, perekonomian negara Indonesia menunjukkan kondisi yang kurang menggembirakan bagi para pelaku usaha dan masyarakat. Tingginya angka inflasi nasional pada tahun 2005-2014 yang mencapai $8 \%$ dan isu kenaikan maupun kelangkaan harga BBM menjadi bukti adanya kurang kondusifnya kondisi perekonomian negara. Dalam kondisi yang seperti ini, masyarakat semakin terpuruk ketika harga kebutuhan beberapa bahan pokok mengalami peningkatan dan tidak lagi terjangkau yang juga tidak diimbangi 
dengan meningkatnya pendapatan masyarakat.

Bagi para pelaku usaha, kondisi yang perlu diperhatikan adalah mengenai bagaimana daya beli masyarakat di sekitar sehingga bisa memunculkan permintaan dari beberapa penawaran yang dilakukan oleh perusahaan. Apabila permintaan meningkat memungkinkan pasar menjadi potensial dan ketika kondisi permintaan menurun menyebabkan kondisi pasar berada pada posisi yang tidak menguntungkan. Yang perlu diperhatikan adalah mengenai bagaimana tingkat persaingan, daya beli masyarakat, dan hukum permintaan maupun penawaran itu terjadi pada kondisi yang demikian.

Namun berdasarkan pengalaman krisiskrisis sebelumnya, bahwa UMKM yang tetap bertahan terhadap gelombang krisis nasional. Mubyarto, 2003 berpendapat bahwa Ekonomi rakyat di manapun di daerah-daerah benar-benar sudah bangkit, tidak sekedar menggeliat. Usaha-usaha ekonomi rakyat yang disebut (secara tidak tepat) sebagai UKM (Usaha Kecil Menengah) berkembang di mana-mana dengan pendanaan mandiri atau melalui dana-dana keuangan mikro seperti pegadaian, koperasi atau lembaga-lembaga keuangan mikro "informal” di perdesaan. Oleh karena itu UMKM perlu lebih diberdayakan agar lebih dapat berkembang sesuai dengan pertumbuhan kebutuhan masyarakat.

Analisis investasi UMKM Sepatu dan Sandal di Bogor dilakukan untuk mendapatkan gambaran besarnya investasi dan biaya yang harus dikeluarkan dalam membangun usaha tersebut serta besarnya manfaat yang dapat diperoleh oleh stakeholder dari UMKM Sepatu dan Sandal. Analisis kelayakan diantaranya analisa kelayakan finansial usaha dilakukan terhadap usaha UMKM Sepatu dan Sandal yang sudah ada saat ini, untuk mendapatkan gambaran besarnya biaya yang telah dikeluarkan dan dibandingkan dengan besarnya manfaat yang telah diperoleh serta gambaran biaya manfaat di masa akan datang. Berdasarkan hasil analisis finansial tersebut diharapkan dapat dijadikan acuan bagi analisis kelayakan finansial UMKM Sepatu dan Sandal di Bogor khususnya dan Indonesia pada umumnya.

Berdasarkan identifikasi masalah diatas, maka permasalahan dirumuskan sebagai berikut: Bagaimana kelayakan usaha pada UMKM Sepatu dan Sandal di Bogor? Dan strategi apa yang harus dilakukan untuk mengembangkan usaha dalam meningkatkan daya saingnya? Berdasarkan perumusan masalah, maka tujuan dalam penelitian ini adalah sebagai berikut: Untuk mengetahui kelayakan usaha pada UMKM Sepatu dan Sandal di Bogor dan 
Untuk mengetahui strategi yang dilakukan untuk mengembangkan usaha dalam meningkatkan daya saingnya.

\section{TELAAH LITERATUR}

\section{Studi Kelayakan Bisnis}

Studi Kelayakan bisnis adalah suatu kegiatan yang mempelajari secara mendalam tentang kegiatan atau usaha atau bisnis yang akan dijalankan, dalam rangka menentukan layak atau tidak usaha tersebut dijalankan, (Kasmir dan Jakfar,2003:10), objek yang diteliti tidak hanya pada bisnis atau usaha yang besar saja, tapi pada bisnis atau usaha yang sederhana bisa juga diterapkan.

Kelayakan artinya penelitian yang dilakukan secara mendalam tersebut dilakukan untuk menentukan apakah usaha yang akan dijalankan akan memberikan manfaat yang lebih besar dibandingkan dengan biaya yang dikeluarkan. Dengan kata lain kelayakan dapat diartikan bahwa usaha yang dijalankan akan memberikan keuntungan finansial dan non-finansial sesuai dengan tujuan yang mereka inginkan. Layak di sini diartikan juga akan memberikan keuntungan tidak hanya bagi perusahaan yang menjalankannya, akan tetapi juga bagi investor, kreditur, pemerintah dan masyarakat luas.

Pada umumnya studi kelayakan bisnis akan menyangkut tiga aspek (Suad Husnan, 1995:6), yaitu :
1. Manfaat ekonomis bagi usaha itu sendiri (sering pula disebut manfaat finansial). Yang berarti apakah usaha yang akan dijalankan itu dipandang cukup menguntungkan apabila dibandingkan dengan resikonya.

2. Manfaat ekonomis usaha tersebut bagi Negara tempat usaha tersebut dilaksanakan (sering disebut manfaat ekonomi nasional).

3. Manfaat sosial usaha tersebut bagi masyarakat sekitar usaha tersebut.

\section{Tujuan Dilakukan Studi Kelayakan.}

Paling tidak ada lima tujuan mengapa sebelum suatu usaha atau bisnis dijalankan perlu dilakukan studi kelayakan (Kasmir Jakfar,2003:20), yaitu :

1. Menghindari Resiko Kerugian Untuk mengatasi resiko kerugian di masa yang akan datang ada semacam kondisi kepastian. Kondisi ini ada yang dapat diramalkan akan terjadi atau memang dengan sendirinya terjadi tanpa dapat diramalkan. Dalam hal ini fungsi studi kelayakan adalah untuk meminimalkan resiko yang tidak kita inginkan, baik resiko yang dapat kita kendalikan maupun yang tidak dapat dikendalikan

2. Memudahkan Perencanaan Jika kita sudah dapat meramalkan apa 
yang akan terjadi di masa yang akan datang, maka akan mempermudah kita dalam melakukan perencanaan dan halhal apa saja yang perlu direncanakan.

3. Memudahkan Pelaksanaan Pekerjaan Dengan adanya berbagai rencana yang sudah disusun akan sangat memudahkan pelaksanaan usaha. Para pelaksana yang mengerjakan bisnis tersebut telah memiliki pedoman yang harus diikuti. Pedoman tersebut telah tersusun secara sistematis, sehingga usaha yang dilaksanakan dapat tepat sasaran dan sesuai dengan rencana yang sudah disusun.

4. Memudahkan Pengawasan Dengan telah dilaksanakannya suatu usaha sesuai dengan rencana yang sudah disusun, maka akan memudahkan kita untuk melakukan pengwasan terhadap jalannya usaha. Pengawasan ini perlu dilakukan agar tidak melenceng dari rencana yang telah disusun.

5. Memudahkan

Pengendalian Apabila dalam pelaksanaan pekerjaan telah dilakukan pengawasan, maka jika terjadi penyimpangan akan mudah terdeteksi, sehingga dapat dilakukan pengendalian atas penyimpangan tersebut. Tujuan pengendalian adalah untuk mengendalikan pelaksanaan agar tidak melenceng dari rel yang sesungguhnya, sehingga pada akhirnya tujuan perusahaan akan tercapai.

\section{Aspek-aspek Studi Kelayakan Bisnis}

Menurut Husein Umar dalam bukunya Studi Kelayakan Bisnis, Manajemen, Metode dan Kasus, 1997:10, aspek-aspek dalam studi kelayakan meliputi :

1. Aspek Teknis Evaluasi aspek teknis ini mempelajari kebutuhankebutuhan teknis proyek, seperti penentuan kapasitas produksi, jenis teknologi yang digunakan, pemakaian peralatan dan mesin, serta lokasi usaha yang paling menguntungkan

2. Aspek Pasar dan Pemasaran Evaluasi aspek pasar dan pemasaran sangat penting dilakukan karena tidak ada usaha yang berhasil tanpa adanya permintaan atas barang atau jasa yang dihasilkan oleh usaha tersebut. Pada dasarnya, aspek pasar dan pemasaran bertujuan untuk mengetahui berapa besar luas pasar, pertumbuhan permintaan dan pangsa pasar 
produk atau jasa yang bersangkutan.

3. Aspek Yuridis Evaluasi terhadap aspek yuridis perlu dilakukan. Bagi pemilik usaha, evaluasi ini berguna antara lain untuk kelangsungan usaha serta dalam rangka meyakinkan para kreditur dan investor bahwa usaha yang akan dilakukan tidak menyimpang dari aturan yang berlaku.

4. Aspek Manajemen Dalam aspek manajemen yang dievaluasi ada dua macam, yang pertama manajemen saat pembangunan usaha dan yang kedua manajemen saat usaha dioperasionalkan. Banyak terjadi usaha-usaha yang gagal dibangun maupun dioperasionalkan bukan disebabkan karena aspek lain, tetapi karena lemahnya manajemen.

5. Aspek Lingkungan Pertumbuhan dan perkembangan perusahaan tidak dapat dilepaskan dari lingkungan sekitarnya. Lingkungan ini dapat berpengaruh positif maupun negatif perusahaan, sehingga studi kelayakan aspek ini perlu dianalisis pula.

6. Aspek Finansial Dari sisi keuangan, usaha sehat dikatakan apabila dapat memberikan keuntungan yang layak dan mampu memenuhi kewajiban finansialnya. Kegiatan ini dilakukan setelah aspek lain selesai dilaksanakan. Kegiatan pada aspek finansial ini antara lain menghitung perkiraan jumlah dana yang diperlukan untuk keperluan modal awal dan untuk pengadaan harta tetap usaha

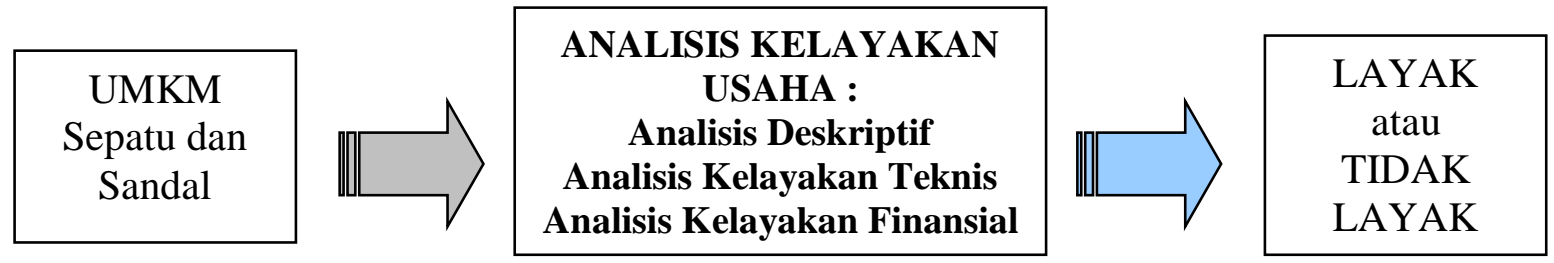

Gambar 1. Kerangka Pemikiran

(Sumber: Penulis - diolah) 


\section{METODOLOGI PENELITIAN}

Metode penelitian yang dipergunakan adalah metode deskriptif. Menurut Kusmayadi dan Sugiarto (2000:29) pengertian dari metode penelitian deskriptif adalah : "Penelitian yang berusaha mendeskriptifkan atau manggambarkan atau melukiskan fenomena atau hubungan antar-fenomena yang diteliti dengan sistematis, faktual, dan akurat."

Unit analisis adalah unit yang diamati adalah bentuk usaha dan organisasi, production cost dan laporan keuangan serta laporan penjualan dari tahun 2011 sampai dengan 2015. Penelitian akan dilakukan di kawasan UMKM Sepatu dan Sandal di Desa Pasir Eurih, Kecamatan Tamansari Kabupaten Bogor. Penelitian diawali dengan pengumpulan data. Data yang diperoleh selanjutnya dianalisis dengan beberapa metode yaitu Payback Period (PP), Net Present Value (NPV), Internal Rate of Return (IRR), Profitability Index (PI) serta Net B/C serta Break EvenPoint (BEP).

\section{Pengumpulan Data}

Data yang dibutuhkan terdiri dari data primer dan data sekunder. Data primer diperoleh melalui pengisian kuesioner dan yang disertai dengan wawancara langsung dari nara sumber
Komponen utama dari kuesioner yang diajukan yakni :

1. identifikasi perusahaan (ijin usaha dll.)

2. identifikasi bahan baku yang terdiridari asal sumber bahan baku dan jenis bahan baku serta besarnya jumlah bahan baku dalam per hari,

3. identifikasi teknologi pengolahan,

4. identifikasi sumberdaya manusia yang digunakan meliputi jumlah tenaga kerja dan sistem pembagian kerja yang diterapkan,

5. identifikasi peralatan dan mutu produk,

6. identifikasi komponen biaya investasi pengolahan diantaranya biaya bangunan, mesin dan alat, transportasi, serta sarana pendukung lainnya,

7. identifikasi komponen biaya produksi diantaranya biaya bahan baku, upah tenaga kerja, administrasi umum, eksploitasi dan perawatan serta biaya lainnya,

8. identifikasi pemasaran dan

9. identifikasi komponen pendapatan harga jual dan jumlah produksi per hari. 
Sedangkan data sekunder diperoleh melalui bahan publikasi yang diterbitkan oleh instansi terkait dan berhubungan langsung dengan studi ini.

\section{Jenis, Sumber Data dan Metode}

\section{Pengumpulan Data}

Supranto (2001:23) menjelaskan, “Apabila metode pengumpulan data sudah ditemukan, kemudian ditentukkan alat untuk memperoleh data dari objek yang diteliti”. Alat untuk memperoleh keterangan dari objek atau elemen antara lain :

Daftar pertanyaan / suara angket (kuesioner)

1. Wawancara

2. Observasi atau pengamatan langsung

3. Melalui internet, telepon, atau alat komunikasi lainnya.

Prosedur pengumpulan data yang digunakan dalam penelitian ini melalui dua cara, yaitu:

Data yang dibutuhkan terdiri dari data primer dan data sekunder. Data primer diperoleh melalui pengisian kuesioner dan yang disertai dengan wawancara langsung dari nara sumber yang antara terdiri dari atas :

1. Pejabat Pemerintah terkait (Bupati, Dinas Kesehatan, Ketahanan Pangan, dll), untuk

mengetahui kebijakan yang
diambil dalam usaha
mendorong UMKM khususnya
masalah perijinan dan lain-
lainnya.

2. Stakeholder usaha sepatu dan sandal.

Data sekunder diperoleh dari literatur dan buku-buku teori pendukung sebagai pelengkap data primer seperti catatan dari para pengerajin sepatu sandal.

Objek penelitian untuk penelitian ini adalah UMKM Sepatu dan Sandal Desa Pasir Eurih sehingga seluruh keterangan yang didapat dari UMKM ini menjadi bahan penulisan. Analisis yang digunakan dalam studi ini adalah :

Analisis Deskriptif yang meliputi,

a) Kecenderungan (trend) produksi;

b) Potensi pemasaran;

c) Pendapatan per kapita masyarakat dan perkembangan penduduk;

d) Dampak lingkungan.

Analisis Kelayakan Teknis, yang mencakup :

a) Analisis bahan baku;

b) Analisis sumber daya manusia;

c) Analisis infrastruktur jalan, listrik, telepon, dll.

d) Peneliti menggunakan nilai $1-5$ untuk mengukur indikator indikator yang digunakan dalam analisis kelayakan teknis, di mana: 
Tabel 1. Kriteria Penilaian Analisis Kelayakan Teknis

\begin{tabular}{cl}
\hline Nilai & \multicolumn{1}{c}{ Kriteria } \\
\hline 1 & Tidak Baik \\
2 & Kurang Baik \\
3 & Baik \\
4 & Cukup Baik \\
5 & Sangat Baik \\
\hline
\end{tabular}

Sumber : Data Diolah Peneliti

\section{Teknik Analisis Kelayakan Finansial}

Dalam menjalankan usaha pada umumnya menggunakan metode-metode penilaian investasi yang diantaranya adalah dengan

Payback Period $=\frac{\text { Initial Investment }}{\text { Cash Flow }}$

Jika nilai dari payback period > umur ekonomis maka Investasi ditolak. Jika nilai dari payback period < umur ekonomis maka Investasi diterima. Jadi kriteria penilaian pada metode payback period ini adalah jika payback periodnya lebih kecil dari waktu maksimum yang disyaratkan maka proyek diterima, dan sebaliknya bila payback periodnya lebih besar atau lebih lama dari waktu yang diisaratkan maka investasi ditolak.

Metode payback period merupakan metode penilaian investasi yang sangat sederhana perhitungannya, sehingga banyak digunakan oleh perusahaan. Tetapi menggunakan metode Payback Period / Payback Method

Rumus Payback Period jika arus kas dari suatu rencana investasi/proyek berbeda jumlahnya setiap tahun:

di lain pihak metode ini mempunyai kelemahan-kelemahan, yaitu:

1. Tidak memperhatikan nilai waktu uang.

2. Mengabaikan arus kas masuk yang diperoleh sesudah payback period suatu rencana investasi tercapai.

3. Mengabaikan nilai sisa (salvage value) investasi.

Meskipun metode payback period memiliki beberapa kelemahan, namun metode ini masih terus digunakan secara intensif dalam membuat keputusan investasi, tetapi metode ini tidak digunakan sebagai alat utama melainkan 
hanya sebagai indikator dari likuiditas dan risiko investasi.

Keunggulan metode payback period adalah sebagai berikut:

1. Perhitungannya mudah dimengerti dan sederhana.

2. Mempertimbangkan arus kas dan bukan laba menurut akuntansi.

3. Sebagai alat pertimbangan risiko karena makin pendek payback makin rendah risiko kerugian.

\section{Teknik Analisis NPV}

Teknik analisis NPV sangat bermanfaat untuk menilai kelayakan suatu proyek dengan menghitung nilai penerimaan sekarang dan yang akan datang. Penilaian proyek dilakukan dengan mengukur prospek penerimaan sekarang atas sejumlah dana dengan mempertimbangkan penerimaan di masa yang akan datang. Apabila dari hasil perhitungan, NPV bernilai positif maka rencana proyek layak untuk dilanjutkan, demikian pula sebaliknya.

Net Present Value (NPV) atau nilai bersih sekarang merupakan selisih antara pengeluaran dan pemasukan yang telah didiskon dengan menggunakan social opportunity cost of capital sebagai diskon faktor, atau dengan kata lain merupakan arus kas yang diperkirakan pada masa yang akan datang yang didiskontokan pada saat ini. Untuk menghitung NPV diperlukan data tentang perkiraan biaya investasi, biaya operasi, dan pemeliharaan serta perkiraan manfaat/benefit dari proyek yang direncanakan. Jadi perhitungan NPV mengandalkan pada teknik arus kas yang didiskontokan.

Menurut Kasmir (2003:157) Net Present Value (NPV) atau nilai bersih sekarang merupakan perbandingan antara PV kas bersih dengan PV Investasi selama umur investasi. Sedangkan menurut Ibrahim (2003:142) Net Present Value (NPV) merupakan net benefit yang telah di diskon dengan menggunakan social opportunity cost of capital (SOCC) sebagai discount factor.

Rumus dari NPV adalah sebagai berikut :

$\mathrm{PV}=\mathrm{R}_{\mathrm{t}} /(1+\mathrm{i})^{\mathrm{t}}$

Di mana:

$\mathrm{t}=$ waktu arus kas

$\mathrm{i}=$ suku bunga diskonto yang digunakan

$\mathrm{Rt}=$ arus kas bersih (the net cash flow) dalam waktu t

\section{Kriteria NPV :}

$\mathrm{NPV}>0$, Investasi yang dilakukan memberikan manfaat bagi perusahaan, proyek bisa dijalankan.

$\mathrm{NPV}>0$, Investasi yang dilakukan memberikan manfaat bagi perusahaan,proyek ditolak.

$\mathrm{NPV}=0$, Investasi yang dilakukan mengakibatkan keuntungan atau kerugian bagi perusahaan. 
Langkah menghitung NPV:

1. Tentukan nilai sekarang dari setiap arus kas, termasuk arus masuk dan arus keluar, yang didiskontokan pada biaya modal proyek,

2. Jumlahkan arus kas yang didiskontokan ini, hasil ini didefinisikan sebagai NPV proyek,

3. Jika NPV adalah positif, maka proyek harus diterima, sementara jika NPV adalah negatif, maka proyek itu harus ditolak. Jika dua proyek dengan NPV positif adalah mutually exclusive, maka salah satu dengan nilai NPV terbesar harus dipilih. NPV sebesar nol menyiratkan bahwa arus kas proyek sudah mencukupi untuk membayar kembali modal yang diinvestasikan dan memberikan tingkat pengembalian yang diperlukan atas modal tersebut. Jika proyek memiliki NPV positif, maka proyek tersebut menghasilkan lebih banyak kas dari yang dibutuhkan untuk menutup utang dan memberikan pengembalian yang diperlukan kepada pemegang saham perusahaan.

Keunggulan NPV = menggunakan konsep nilai waktu uang (time value of money).
Maka sebelum penghitungan/penentuan NPV hal yang paling utama adalah mengetahui atau menaksir aliran kas masuk di masa yang akan datang dan aliran kas keluar.

Di dalam aliran kas ini, ada beberapa hal yang perlu diperhatikan :

1. Taksiran kas haruslah didasarkan atas dasar setelah pajak,

2. Informasi terebut haruslah didasarkan atas "incremental" (kenaikan atau selisih) suatu proyek. Jadi harus diperbandingkan adanya bagaimana aliran kas seandainya dengan dan tanpa proyek. Hal ini penting sebab pada proyek pengenalan produk baru, bisa terjadi bahwa produk lama akan "termakan" sebagian karena kedua produk itu bersaing dalam pemasaran,

3. Aliran kas ke luar haruslah tidak memasukkan unsur bunga, apabila proyek itu direncanakan akan dibelanjai/didanai dengan pinjaman. Biaya bunga tersebut termasuk sebagai tingkat bunga yang disyaratkan (required rate of return) untuk penilaian proyek tersebut. Kalau kita ikut memasukkan unsur bunga di dalam perhitungan aliran kas ke 
luar, maka akan terjadi perusahaan ingin mengetahui persentase penghitungan ganda.

dari pengambilan penanaman setelah dikonversi kedalam nilai sekarang. Internal

\section{Internal Rate of Return}

Nilai sekarang bersih atau Net Persent Rate of Return adalah tingkat diskonto ( discount rate) yang menjadikan sama Value kadang-kadang kurang lengkap antara present value dari penerimaan cash untuk digunakan sebagai satu-satunya dan present value dari nilai investasi penilaian investasi. Karena dalam nilai sekarang bersih hanya diketahui bahwa discount rate/tingkat diskonto yang menunjukkan net present value atau sama besarnya dengan nol.

Rumus dari Internal Rate of Return adalah sebagai berikut :

dari hasil diatas investasi awal secara persentase tidak diketahui, oleh karena itu

$$
\mathrm{IRR}=\mathrm{i}_{1}+\frac{\mathrm{NPV}_{1}}{\mathrm{NPV}_{1}-\mathrm{NPV}_{2}} \quad \mathrm{x}\left(\mathrm{i}_{2}-\mathrm{i}_{1}\right)
$$

Di mana:

$$
\begin{array}{ll}
\text { i } 1=\text { Tingkat bunga ke- } 1 & \text { NPV1 }=\text { NPV positif } \\
\text { i } 2=\text { Tingkat bunga ke- } 2 & \text { NPV2 }=\text { NPV negatif }
\end{array}
$$

Metode ini diterapkan dengan prosedur :

1. Mencari nilai sekarang bersih dari investasi.

2. Apabila nilai sekarang bersih positif, maka tingkat hasildinaikkan sampai menunjukkan nilai sekarang bersih negatif. Atau sebaliknya apabila nilai sekarang bersih negatif, maka tingkat hasil sampai nilai sekarang bersih positif.

Kriteria penilaian dengan menggunakan metode ini adalah bila nilai IRR yang didapat lebih besar dari tingkat bunga uang yang berlaku dalam masyarakat, maka investasi diterima. Dan sebaliknya, bila nilai IRR lebih kecil dari tingkat bunga yang berlaku dalam masyarakat, maka investasi ditolak (H.M. Yacob Ibrahim, 1997:150).

Kelemahan - kelemahan pada metode IRR adalah :

1. Tingkat diskonto yang dihitung akan merupakan nilai yang sama untuk setipa tahun ekonomisnya. Metode IRR tidak memungkinkan menghitung IRR yang mungkin berbeda stiap tahunnya. Padahal secara toritis dimungkinkan 
terjadi tingkat bunga yang

berbeda setiap tahun.

\section{Average Rate of Return}

2. Bisa diperoleh i yang lebih dari Metode Average Rate or Return atau satu angka ( multiple IRR ). sering disebut juga dengan Accounting Dengan demikian timbul masalah, yaitu i mana yang akan kita pergunakan.

3. Pada saat perusahaan harus memilih proyek yang bersifat mutually exclusive, kita mungkin salah memilih proyek kalau kita Rate of Return, menunjukkan persentase keuntungan neto sesudah pajak dihitung dari Average Investment atau Initial Investment. Metode ini mendasarkan diri pada keuntungan yang dilaporkan dalam buku (Reported Accounting Income), (Bambang Riyanto, 1995:134).

menggunakan kriteria IRR.

Rumus yang digunakan adalah :

Penggunaan IRR akan tepat kalau

dipergunakan Incremental IRR.

$$
\mathrm{ARR}=\frac{\text { Rata-rata EAT (Average Earning After Tax) }}{\text { Rata-rata Investasi (Average Investment) }} \quad \mathrm{X} 100 \%
$$

Kriteria ARR :

Jika ARR > $100 \%$ maka investasi diterima

Jika ARR < $100 \%$ maka investasi ditolak

Metode ARR mempunyai kelemahan kelemahan antara lain :

1. Perhitungan ARR tidak memperhatikan time value of money

2. Menitik beratkan pada perhitungan accounting dan bukan pada cash flow dari investasi yang bersangkutan, sehingga suatu investasi yang mempunyai umur penyusutan lebih cepat akan mengakibatkan keuntungan neto yang lebih rendah dan di satu pihak meninggikan cash flow, oleh karena penyusutan bukan merupakan pengeluaran kas. ARR dapat dianalisa dengan beberapa cara, sehingga diperlukan standar perbandingan yang sesuai dengan cara - cara tersebut dan dimungkinkan dapat terjadi kesalahan memperbandingkan. 
Profitability Index

Profitability Index (PI) atau benefit and cost ratio (B\C Ratio) merupakan rasio aktifitas dari jumlah nilai sekarang penerimaan bersih dengan nilai sekarang

$$
\mathrm{PI}=\frac{\text { PV. Proceed }}{\text { PV. Outlays }}
$$

pengeluaran investasi selama umur investasi (Kasmir dan Jakfar, 2003:163). Rumus yang digunakan untuk mencari PI adalah sebagai berikut :

Kelayakan investasi menurut standar analisa ini adalah :

Jika PI > 1 ; maka investasi tersebut dapat dijalankan (layak/ feasible)

Jika PI $<1$; investasi tersebut tidak layak dijalankan (tidak layak/ not feasible)

Metode ini menghitung perbandingan antara nilai arus kas bersih yang akan datang dengan nilai investasi yang sekarang. Profitability Index harus lebih besar dari 1 baru dikatakan layak. Semakin besar PI, investasi semakin layak.

Kelebihan Profitability Index adalah :

1. Memberikan percentage future cash flows dengan cash initial

2. Sudah mempertimbangkan cost of capital

3. Sudah mempertimbangkan time value of money

4. Mempertimbangkan semua cash flow
Kekurangan Profitability Index adalah :

1. Tidak memberikan informasi mengenai return suatu project.

2. Dibutuhkan cost of capital untuk menghitung Profitability Index.

3. Tidak memberikan informasi mengenai project risk. Susah dimengerti untuk dijadikan indicator apakah suatu project memberikan value kepada perusahaan.

Peneliti menggunakan nilai 1 - 5 untuk mengukur indikator - indikator yang digunakan dalam analisis kelayakan finansial, dimana: 
Tabel 2. Kriteria Penilaian Analisis Kelayakan Finansial

\begin{tabular}{|c|c|c|c|}
\hline Kriteria/ Nilai & 0 & 3 & 5 \\
\hline Payback Period & $>2$ & $=2$ & $<2$ \\
\hline NPV & $<0$ & $=0$ & $>0$ \\
\hline IRR & $<\mathrm{R}$ & $=\mathrm{R}$ & $>\mathrm{R}$ \\
\hline ARR & $<100 \%$ & $=100 \%$ & $>100 \%$ \\
\hline PI & $<1$ & $=1$ & $>1$ \\
\hline
\end{tabular}

Sumber : Data Diolah Peneliti

\section{Analisis SWOT (Strength, Weakness,}

\section{Opportunity, and Threat)}

Analisis SWOT (Strength, Weakness, Opportunity, and Threat) dilakukan untuk menjawab tujuan dan maksud penelitian tentang strategi pengembangan yang perlu diterapkan untuk meningkatkan kinerja usaha kerajinan sepatu. Analisis SWOT merupakan alat analisis yang dapat digunakan untuk menyusun strategi pengembangan usaha berdasarkan kekuatan, kelemahan, peluang dan ancaman yang dimiliki oleh suatu perusahaan.

Menurut Rangkuti (2006) Kekuatan dan kelemahan merupakan faktor internal, yakni hal-hal yang berasal dari dalam diri sendiri. Sedangkan peluang dan ancaman merupakan faktor eksternal, yakni faktor luar yang banyak mempengaruhi kinerja usaha kerajinan sepatu.

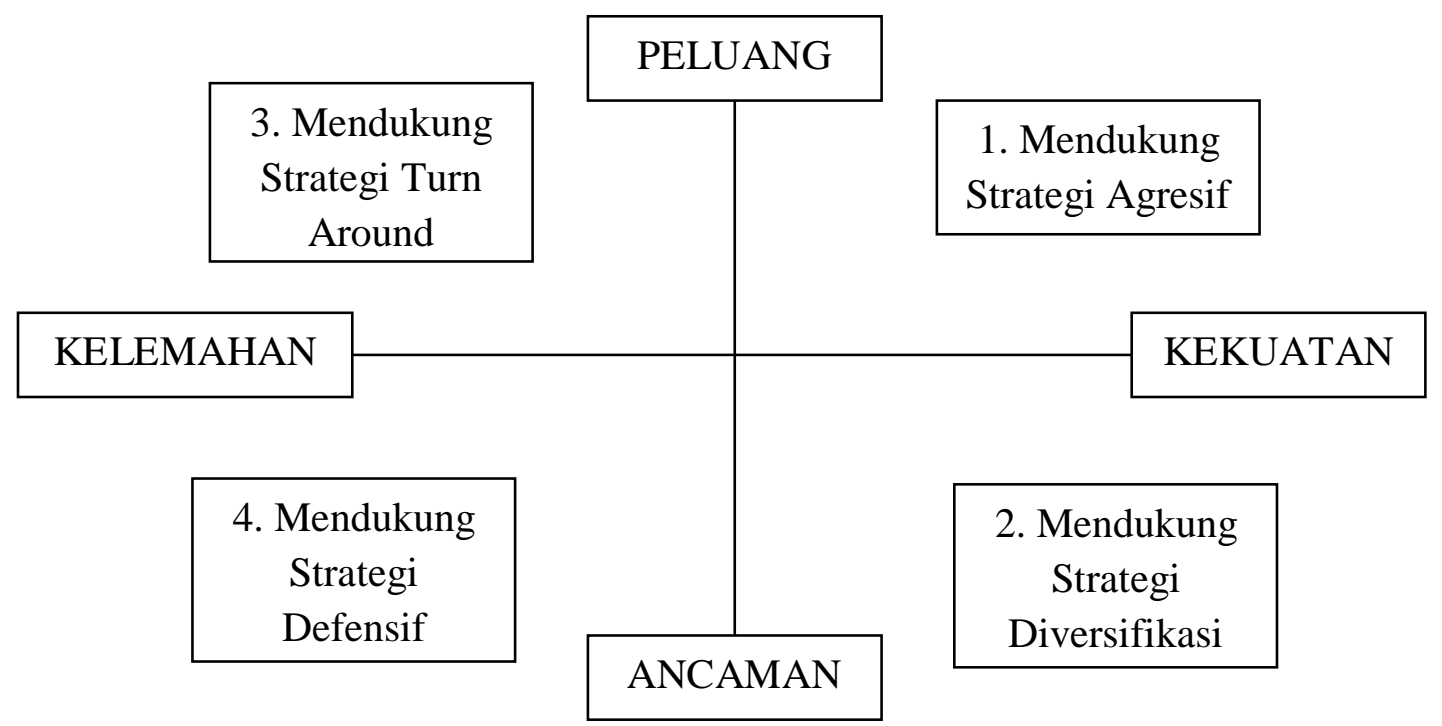

Gambar 2. Diagram Analisis SWOT 
Penjelasan:

Kuadran 1 : ini merupakan situasi yang sangat menguntungkan. Perusahaan tersebut memiliki peluang dan kekuatan sehingga dapat memanfaatkan peluang yang ada. Strategi yang harus diterapkan dalam kondisi ini adalah mendukung kebijakan pertumbuhan yang agresif.

Kuadran 2 : meskipun menghadapai berbagai ancaman, perusahaan masih memiliki kekuatan dari segi internal. Strategi yang harus diterapkan adalah menggunakan kekuatan untuk memanfaatkan peluang jangka panjang dengan cara strategi diversifikasi (produk/pasar).

Kuadran 3 : perusahaan menghadapi peluang pasar yang sangat besar, tetapi dilain pihak, perusahaan menghadapi beberapa kendala atau kelemahan internal. Fokus strategi perusahaan adalah meminimalkan masalahmasalah internal perusahaan sehingga dapat merebut peluang pasar yang lebih baik.
Kuadran 4 : merupakan situasi yang sangat tidak menguntungkan, perusahaan tersebut menghadapi berbagai ancaman dan kelemahan internal.

\section{HASIL \& ANALISIS}

Dikutip dari berbagai sumber bahwa Usaha kecil dan menengah (UKM) sepatu di daerah Bogor muncul sekitar tahun 1920-an di daerah Ciomas. Sampai dengan tahun 1950-an pembuatan sepatu masih merupakan pekerjaan yang dilakukan individu atau usaha rumah tangga, yang memproduksi sepatu kulit berkualitas tinggi. Perkembangan industri ini ditandai dengan berdirinya sebuah bentuk usaha bersama dalam wadah Persebo (Perusahaan Sepatu Bogor). Koperasi ini beranggotakan para pengrajin sepatu yang melayani order untuk memenuhi kebutuhan sepatu militer, dan juga untuk membantu pemasaran produk-produk bengkel disekitarnya. Persebo berperan penting dalam pertumbuhan pengrajin sepatu di desa-desa sekitar Ciomas, sampai ketika terjadi resesi ekonomi pada tahun 1960-an yang mengakibatkan perubahanperubahan penting dalam struktur internal dan eksternal pada industri ini. Pada tahun 1970-an, pemilik modal besar mulai melibatkan diri dan memperkenalkan sistem pembayaran dengan menggunakan 
"bon". Kemudian pada tahun 1991 terbentuk kembali Koperasi Sepatu Perkasa Mas dan Koperasi Warga Sepatu Ciomas. Namun koperasi ini tidak berjalan sebagaimana yang diharapkan. Dari hasil wawancara dengan pemilik usaha, ketidakberhasilan koperasi sepatu tersebut disebabkan oleh faktor sumberdaya manusia yang terlibat dalam koperasi itu sendiri, baik pengurus maupun anggotanya. Sistem Permodalan yang berlaku pada UKM sepatu di daerah Ciomas sebagian besar adalah sistem bon putih, yaitu sistem kerjasama Produksi antara pihak pengusaha sepatu sebagai produsen dan pihak pemberi order (Grosir) sebagai konsumen. Sistem bon putih ini mampu memenuhi kekurangan pengusaha industri kecil sepatu-sandal di daerah Ciomas dalam hal permodalan dan bahan baku. Sepatu-sandal yang dihasilkan industri ini bermacam-macam ukurannya, mulai dari yang kecil sampai yang besar untuk pria dan wanita. Sejak enam tahun terakhir ini sepatu dan sandal wanita merupakan produk yang paling banyak diminati dan paling banyak permintaannya, karena sesuai dengan perkembangan mode. Pada saat musim ramai, menjelang Lebaran dan Natal seluruh bengkel sibuk menerima pesanan sepatu dan sandal dari konsumen (Grosir), dan biasanya pekerjaan dapat berlangsung dari pagi sampai larut malam, sedangkan bila tidak sedang ramai pekerjaan berlangsung dari pukul 08.00-16.00 petang. Dimusim-musim sepi, industri sepatu mengurangi tenaga kerjanya dan buruh-buruh mencari pekerjaan lain di sekitar daerah ciomas. Sistem upah yang berlaku didasarkan pada sistem borongan, di mana buruh dibayar berdasarkan jumlah sepatu yang dihasilkan (per kodi sepatu). Upah buruh bervariasi berdasarkan tingkat kesulitan pembuatan sepatu.

Para pengusaha UKM sepatu di daerah Ciomas sebagian besar tidak memiliki sistem pencatatan dan pembukuan yang jelas, sehingga mereka tidak tahu secara pasti apakah mereka memperoleh untung atau mengalami kerugian. Industri kerajinan sepatu di Kecamatan Ciomas Kabupaten Bogor umumnya menghasilkan sepatu dan sandal dengan semua ukuran baik untuk pria maupun untuk wanita. Bahan baku yang digunakan untuk membuat sepatu dan sandal adalah kulit imitasi serta bahan lain yang digunakan yaitu lapis (AC), lateks, sol, tamsin, spon, hak, lem, tekson, dus, pengeras, benang, dll. Bahan-bahan ini diperoleh dari toko bahan di kota Bogor. Bagi pengusaha yang memiliki modal cukup, maka bahan baku dapat mereka peroleh sesuai dengan harga pasar, sedangkan pengusaha yang lemah dalam hal permodalan, maka bahan baku mereka peroleh dengan modal kepercayaan dan kesepakatan dengan 
pihak Grosir, dengan sistem hubungan sub kontrak komersial atau sering disebut "bon putih". Selain sistem bon putih pembelian bahan baku juga biasa diberikan dengan sistem giro dengan tempo waktu satu bulan sampai dengan dua bulan, namun dengan menggunakan kedua sistem ini pengusaha sepatu akan sangat banyak memperoleh (charge) dan harga yang berlaku pun bukan lagi harga pasar, sehingga mereka akan sangat dirugikan.

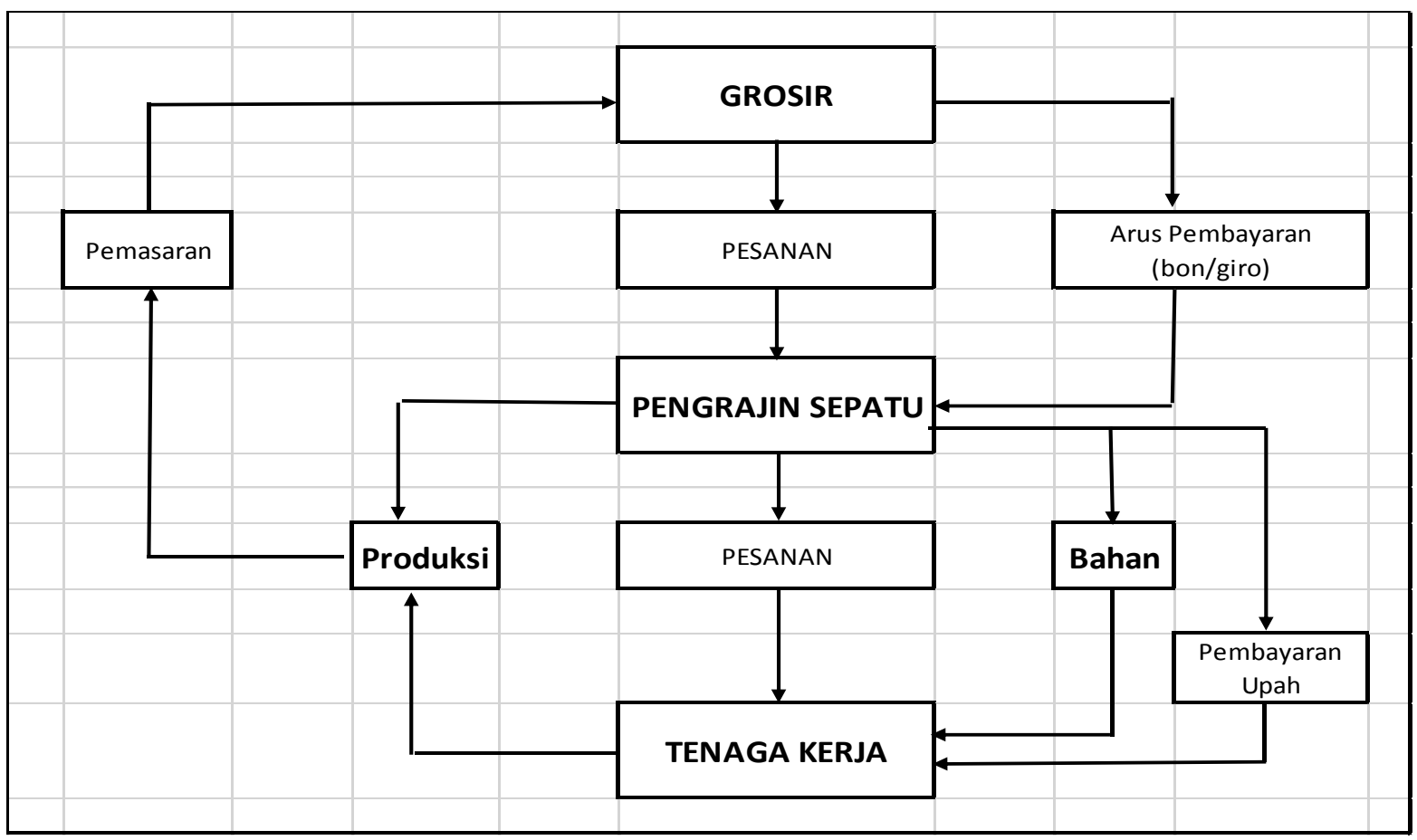

Gambar 3. Mekanisme Hubungan Sub-Kontrak Komersial UKM Sepatu dan Sandal

Sumber : Data Diolah Peneliti

Dengan kedua sistem ini pengusaha diminta untuk memproduksi sepatu sesuai dengan model atau tipe yang ditentukan oleh pihak Grosir. Modal awal untuk mendapatkan bahan baku diberikan oleh pihak Grosir berupa selembar bon putih atau selembar giro dengan cap/identitas Grosir untuk dibelanjakan pada toko bahan yang telah ditentukan, dengan jumlah pesanan untuk satu minggu. Pemberian bon putih atau giro ini dihitung sebagai uang muka dari total pembayaran, yaitu sekitar 50 sampai 60 persen. Selanjutnya pengusaha akan memproduksi di bengkel miliknya dengan melibatkan tenaga kerja. Pada saat pengiriman barang, pihak grosir akan memberikan sejumlah uang untuk membayar tenaga kerja, dengan memperhitungkan modal awal yang telah diambil melalui bon putih atau giro, sisanya dibayar dengan menggunakan giro berjangka waktu satu atau dua bulan yang dapat ditukarkan dengan uang tetapi dengan potongan tertentu. Dengan 
demikian pengrajin/tenaga kerja juga akan bergantung pada jumlah pesanan yang diterima dari pihak grosir.

Karakterikstik dalam penelitian ini adalah para pengrajin UMKM yang memproduksi
Sepatu dan Sandal dan berlokasi di Desa Pasir Eurih, Kecamatan Tamansari, Kabupaten Bogor. Adapun identitas responden adalah sebagai berikut:

\section{Tabel 3. Identitas Responden}

\begin{tabular}{clc}
\hline No & KARAKTERISTIK RESPONDEN \\
\hline 1 & Jenis Kelamin & $90 \%$ Pengrajin adalah Pria \&dibantu oleh anggota keluarga \\
2 & Umur & $>40$ Tahun \\
3 & Status & Menikah \\
4 & Jumlah Anggota Keluarga & $>2$ orang \\
5 & Pekerjaan Utama & Pengrajin Sepatu dan Sandal \\
\hline
\end{tabular}
Sumber : Data Diolah Peneliti

Para Pengrajin berada di lokasi atau kelompok tertentu, atau untuk pemukiman atau lingkungan masyarakat, menentukan frekuensi atau untuk hal tersebut dilakukan untuk menghemat pengeluaran jika dibandingkan dengan menyewa tempat di kios, pasar atau kawasan industri.

\section{Analisis Deskriptif}

Analisis bertujuan menggambarkan secara tepat sifat suatu individu, keadaan, gejala, menentukan frekuensi atau penyebaran suatu gejala, atau frekuensi adanya hubungan tertentu antar suatu gejala dan gejala lain dalam masyarakat.

\section{Kecenderungan (Trend) Produksi}

Ideal produksi sepatu dan sandal dalam 1 minggu adalah 40 kodi dengan tenaga kerja 6 orang.

Tabel 4. Trend Produksi Pengrajin Sepatu dan Sandal dalam 1 Tahun

\begin{tabular}{clrl}
\hline No & Bulan & Jumlah (Kodi) & Keterangan \\
\hline 1 & Januari & 50 & \\
2 & Februari & 50 & Imlek \\
3 & Maret & 20 & \\
4 & April & 50 & \\
5 & Mei & 50 & Paskah \\
6 & Juni & 50 & Idul Fitri \\
7 & Juli & 50 & Anak Sekolah \\
8 & Agustus & 20 & \\
9 & September & 50 & Idul Adha \\
10 & Oktober & 20 & \\
11 & November & 50 & \\
12 & Desember & 50 & Natal dan Tahun Baru \\
& Total & $\mathbf{5 1 0}$ & \\
\hline
\end{tabular}

Sumber : Data Diolah Peneliti 


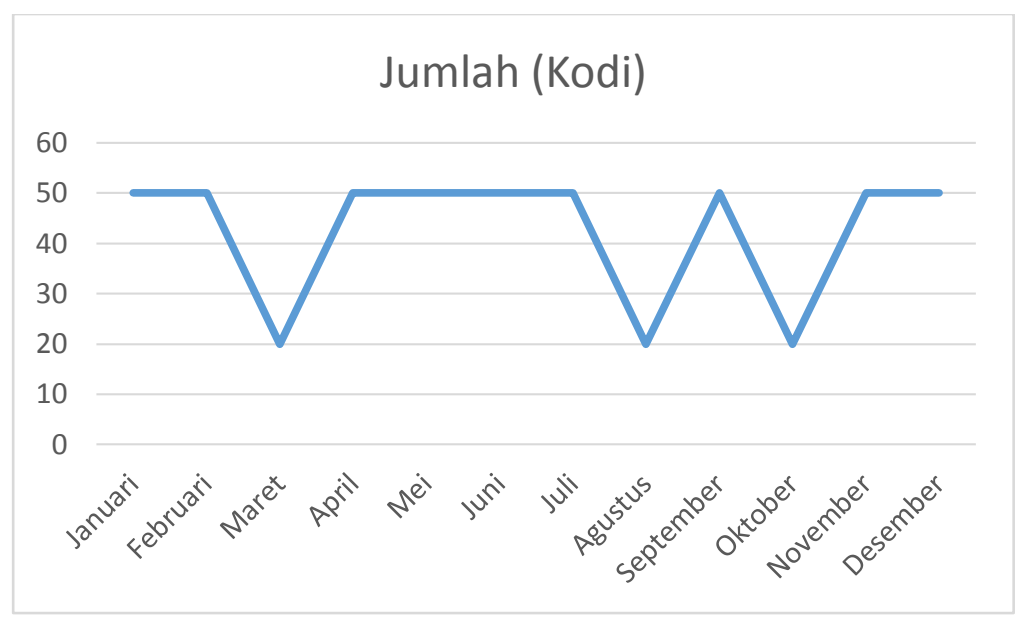

Gambar 4. Trend Produksi Pengrajin Produksi Sepatu dan Sandal dalam 1 Tahun

Pada saat musim ramai, menjelang masuk anak sekolah, Lebaran, Natal, dan hari raya besar lainnya, seluruh bengkel sibuk menerima pesanan sepatu dan sandal dari konsumen (Grosir), dan biasanya pekerjaan dapat berlangsung dari pagi sampai larut malam, sedangkan bila tidak sedang ramai pekerjaan berlangsung dari pukul 08.00-16.00 petang. Dimusimmusim sepi, industri sepatu dan sandal mengurangi tenaga kerjanya dan buruhburuh mencari pekerjaan lain di sekitar daerah Desa Pasir Eurih.

\section{Potensi Pemasaran}

Berdasarkan hasil wawancara, didapatkan bahwa usaha UMKM Sepatu dan Sandal adalah pada satu grosir tetap yang selama ini menjadi mitra pengrajin. Ketergantungan dan keterikatan kepada satu grosir sebagai pihak penyedia modal disebabkan industri alas kaki ini masih dalam skala kecil dan belum memiliki modal yang cukup. Pola pemasaran yang dilakukan para Pengrajin cenderung konvensional. Bahkan cenderung dilakukan secara pasif. Mayoritas para Pengrajin menunggu order dari pengusaha atau pedagang sepatu-sandal. Jika tidak ada order dari para pengusaha tersebut, mereka tidak melakukan produksi. Di sisi lain, potensi pasar masih banyak yang belum digarap dan terbuka luas. Keuntungan dari penjualan produk sepatusandal lebih banyak dinikmati oleh para pedagang. Sedangkan para Pengrajin relatif memperoleh keuntungan yang lebih kecil. Selain itu, meminjam kepada pihak bank juga memiliki banyak hambatan salah satunya dikarenakan tidak adanya laporan keuangan dari pihak industri kecil, sehingga pihak bank sulit menganalisis usaha mereka untuk mencairkan dana. Akibat dari ketergantungan modal dari toko sepatu sandal menjadikan industri kecil alas kaki di Desa Pasir Eurih ini 
sangat terikat dan menjadikan industri kecil memiliki kekuatan tawar menawar yang lemah.

\section{Perkembangan Penduduk dan}

\section{Pendapatan Per Kapita Masyarakat}

Salah satu aset pembangunan yang paling dominan yang dimiliki banyak negara berkembang pada umumnya jumlah penduduk dan angkatan kerja yang demikian besar jumlahnya.

Tabel 5. Jumlah Penduduk Desa Pasir Eurih Tahun 2015

\begin{tabular}{ccrr}
\hline No & Jenis Kelamin & Jumlah & Persentase \\
\hline 1 & Laki-laki & 5.894 & $51,50 \%$ \\
2 & Perempuan & 5.621 & $48,50 \%$ \\
& Jumlah & 11.515 & $100 \%$ \\
\hline
\end{tabular}

Sumber : RKP Desa Pasir Eurih Kecamatan Tamansari

Kabupaten Bogor Tahun 2017

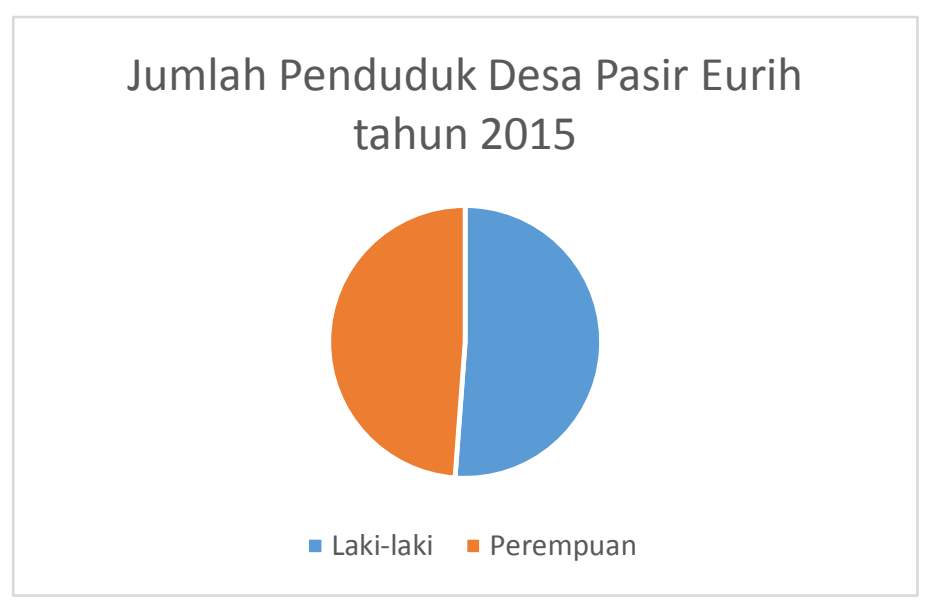

Gambar 5. Jumlah Penduduk Desa Pasir Eurih Tahun 2015

Dari data RKP Desa Pasir Eurih Kecamatan Taman Sari Kabupaten Bogor Tahun 2017 tampak bahwa pada tahun 2015 jumlah penduduk lak-laki adalah 5.894 jiwa dan perempuan 5.621 dengan ratio jenis kelamin $51.5 \%$ banding $48.5 \%$. Sedangkan dari segi struktur penduduk, Desa Pasir Eurih mempunyai struktur penduduk umur Balita, hal ini akan mempengaruhi jumlah angkatan kerja. Partisipasi angkatan kerja merupakan perbandingan antara jumlah angkatan kerja dengan penduduk berumur diatas 10 tahun. Adapun jumlah penduduk berumur diatas 10 tahun adalah 8.840 jiwa dimana 6.125 jiwa adalah penduduk yang bekerja. 
Tabel 6. Trend Produksi Pengrajin Sepatu dan Sandal dalam 1 Tahun

\begin{tabular}{clrrrl}
\hline No & Bulan & $\begin{array}{c}\text { Jumlah } \\
\text { (Kodi) }\end{array}$ & $\begin{array}{c}\text { Harga/ } \\
\text { Kodi }\end{array}$ & Penerimaan & Keterangan \\
\hline 1 & Januari & 50 & 800.000 & 40.000 .000 & \\
2 & Februari & 50 & 800.000 & 40.000 .000 & Imlek \\
3 & Maret & 20 & 800.000 & 16.000 .000 & \\
4 & April & 50 & 800.000 & 40.000 .000 & \\
5 & Mei & 50 & 800.000 & 40.000 .000 & Paskah \\
6 & Juni & 50 & 800.000 & 40.000 .000 & Idul Fitri \\
7 & Juli & 50 & 800.000 & 40.000 .000 & Anak Sekolah \\
8 & Agustus & 20 & 800.000 & 16.000 .000 & \\
9 & September & 50 & 800.000 & 40.000 .000 & Idul Adha \\
10 & Oktober & 20 & 800.000 & 16.000 .000 & \\
11 & November & 50 & 800.000 & 40.000 .000 & \\
12 & Desember & 50 & 800.000 & 40.000 .000 & Natal dan Tahun Baru \\
& Total & $\mathbf{5 1 0}$ & $\mathbf{8 0 0 . 0 0 0}$ & $\mathbf{4 0 8 . 0 0 0 . 0 0 0}$ & \\
\hline
\end{tabular}

Sumber : Data Diolah Peneliti

Berdasarkan data di tabel, pengrajin mampu memproduksi rata-rata 40 kodi per bulan atau setara dengan 480 pasang sepatu/sandal dewasa dengan menggunakan 2 orang tenaga kerja.. Dalam 1 UMKM membutuhkan idealnya 6 orang tenaga kerja. Ideal produksi 1 minggu adalah 40 kodi dengan tenaga kerja 6 orang. Dulu Desa Pasir Eurih disebut dengan Kampung Dolar karena ramainya pengunjung yang datang, terutama saat Indonesia mengalami krisis moneter. Anak dibawah umur 10 tahun sudah dapat membuat sepatu/sandal dan menghasilkan uang. Akibat dari sulitnya mendapatkan tenaga kerja mulai dari tahun 2000, produksi sepatu dan sandal dari Desa Pasir Eurih mulai berkurang tidak maksimal.

\section{Dampak Lingkungan}

Desa Pasir Eurih merupakan anggota dari Forum Desa Wisata Kabupaten Bogor, Bogor Promotion dan Perguruan Tinggi. Salah satu daya tarik alam utama dari desa Pasir Eurih adalah panorama persawahan dan suasana pedesaannya dimana udaranya sejuk dan segar, dengan panorama Gunung Salak serta perkebunan masyarakat dan kerajinan khas Desa Pasir Eurih yaitu sepatu/sandal. Tidak kalah dengan daya tarik alamnya, daya tarik budaya Desa Pasir Eurih juga menarik dimana di desa Pasir Eurih terdapat situs - situs arkeologia peninggalan masa Kerajaan Pajajaran dan Batu Karut. Ditambah lagi dengan fasilitas rumah adat, sanggar seni budaya, seren tahun, adu jaten dan makam tujuh gunung di Kp. Budaya Sindang Baang membuat Desa Pasir Eurih menjadi semakin diminati untuk dikunjungi. Masyarakat di Desa Pasir Eurih 
kebanyakan adalah pengrajin, baik itu pengrajin sepatu dan sandal, pengrajin sangkar burung, dan pengrajin aksesoris. Sedangkan kerajinan lainnya yang diproduksi dari Desa ini adalah kerajinan atap, membatik dan wayang golek.

Desa Pasir Eurih disebut dengan Desa Wisata karena autentik dan unik. Autentik dikarenakan $\quad 70 \% \quad$ masyarakatnya merupakan pengrajin Sepatu dan Sandal. Desa Wisata Pasir Eurih dicanangkan sebagai desa kreatif budaya di Jawa Barat, bahkan satu-satunya untuk perwakilan Kabupaten Bogor. Desa ini memiliki saung informasi wisata, kampong budaya sindang barang dilengkapi dengan Tari Jaipong, Reog, Calung. Angklung Gubrak, KacapiSuling dan Gendang Penca-nya yang khas.

\section{Teknik Analisis Kelayakan Teknis}

Para Pengrajin berada di lokasi pemukiman atau lingkungan masyarakat, hal tersebut dilakukan untuk menghemat pengeluaran jika dibandingkan dengan menyewa tempat di kios, pasar atau kawasan industri.

\section{Analisis Bahan Baku}

Berdasarkan hasil wawancara, didapatkan bahwa pasokan barang pengrajin sepatu berasal dari toko grosir yang berlokasi di sekitar bengkel-bengkel sepatu tempat pengrajin memproduksi sepatu. Dimana pengrajin yang menggunakan sistem bon putih belanja bahan baku ditoko bahan yang sudah bekerjasama dengan pihak Grosir sepatu. Pemasok bahan baku memiliki kekuatan tawar menawar yang tinggi karena mereka menguasai pasar dan memiliki modal yang banyak, sehingga pengusaha sepatu seperti pengrajin yang memiliki keterbatasan modal harus mengikuti harga yang ditetapkan oleh pemasok bahan baku. Pemasok dapat menekan pengrajin yang ada dalam suatu industri dengan cara menaikkan harga serta menurunkan kualitas produk yang dijualnya. Jika pengrajin tidak dapat menutupi kenaikan biayanya melalui struktur harganya, maka kemampuan pengrajin tersebut dapat menurun karena tindakan pemasok tersebut.

\section{Tabel 7. Hasil Penilaian Bahan Baku}

\begin{tabular}{lc}
\hline \multicolumn{1}{c}{ Indikator Ukuran Penilaian Bahan Baku } & Nilai \\
\hline Kualitas & 3 \\
Aksesabilitas & 4 \\
Harga & 2 \\
Nilai rata - rata & 3 \\
\hline
\end{tabular}

Sumber : Data Diolah Peneliti 
Dalam hal ini pengrajin harus menjalin hubungan komunikasi yang baik dengan pemerintah daerah. Para pengrajin juga diharapkan aktif bertukar informasi kepada pemerintah daerah mengenai kondisi yang dihadapi oleh para pengrajin, tidak hanya menunggu uluran bantuan dari pemerintah, namun pengrajin juga aktif menjemput bola mencari informasi maupun bertukar informasi kepada pemerintah mengenai kondisi yang dihadapi pengrajin saat ini. Kehadiran diskusi, memberikan sumbangan pemikiran, penerimaan maupun penolakan program yang telah ditawarkan. Para pengrajin juga diharapkan aktif melaksanakan dialog rutin sesama pengrajin untuk kemudian hasilnya disampaikan kepada pemerintah.
Sehingga diharapkan adanya kebijakan pemerintah daerah mengenai penetapan harga bahan baku dari pemasok yang dapat melindungi pengrajin. Dengan demikian usaha sepatu dan sandal ini layak untuk terus berkembang.

\section{Analisis Sumber Daya Manusia}

Saat ini usaha UMKM Desa Pasir Eurih memiliki hampir 30 pengrajin sepatu dan sandal dan tersebar di sekitar kawasan pemukiman Desa Pasir Eurih.

\section{Usia Pekerja}

Usia pekerja pengrajin sebagian besar pada usia produktif, yakni pada rentang usia 18 - 55 tahun. Adapun data tabel usia penduduk Desa Pasir Eurih adalah sebagai berikut:

Tabel 8. Usia Penduduk Desa Pasir Eurih Tahun 2015

\begin{tabular}{cccc}
\hline No & \multicolumn{1}{l}{ Usia } & Jumlah & Persentase \\
\hline 1 & 0 & 3 & \multicolumn{1}{c}{2} \\
1 & $0-4$ Tahun & 1.780 & $15,31 \%$ \\
2 & $5-9$ Tahun & 1.094 & $9,41 \%$ \\
3 & $10-14$ Tahun & 1.084 & $9,32 \%$ \\
4 & $15-19$ Tahun & 1.056 & $9,08 \%$ \\
5 & 20 - 24 Tahun & 1.061 & $9,13 \%$ \\
6 & 25 - 29 Tahun & 875 & $7,53 \%$ \\
7 & 30 - 34 Tahun & 940 & $8,09 \%$ \\
8 & 35 - 39 Tahun & 871 & $7,49 \%$ \\
9 & 40 - 44 Tahun & 736 & $6,33 \%$ \\
10 & 45 - 49 Tahun & 604 & $5,20 \%$ \\
11 & 50 - 54 Tahun & 454 & $3,91 \%$ \\
12 & 55 - 59 Tahun & 437 & $3,76 \%$ \\
13 & 60 - 64 Tahun & 414 & $3,56 \%$ \\
14 & 65 - 69 Tahun & 174 & $1,50 \%$ \\
15 & 70 Tahun Ke Atas & 45 & $0,39 \%$ \\
& Jumlah & 11.625 & $100 \%$ \\
\hline
\end{tabular}

Sumber : RKP Desa Pasir Eurih Kecamatan Tamansari Kabupaten Bogor Tahun 2017 
Jumlah pengrajin berkurang dikarenakan banyak pemuda setempat yang memutuskan bekerja di bidang lain setelah menyelesaikan sekolah. Selain pengrajin sepatu dan sandal, ada juga pengrajin aksesoris dan pengrajin kuliner yang mendukung Desa Pasir Eurih sebagai Desa wisata. Kurang tertariknya pemuda setempat untuk mengembangkan usaha sepatu dan sandal merupakan salah satu kendala terbesar di Desa Pasir Eurih.

\section{Pendidikan Pekerja}

Pendidikan merupakan suatu hal yang sangat penting dalam menunjang suatu pekerjaan, akan tetapi pendidikan formal tidak begitu diutamakan untuk bekerja sebagai pengrajin sepatu.

Tabel 9. Tingkat Pendidikan Penduduk Desa Pasir Eurih Tahun 2015

\begin{tabular}{clrr}
\hline No & Tingkat Pendidikan Penduduk & Jumlah & Persentase \\
\hline 1 & Tidak Tamat SD & 284 & $2,44 \%$ \\
2 & Tamat SD & 2.692 & $23,16 \%$ \\
3 & Tamat SLTP & 724 & $6,23 \%$ \\
4 & Tamat SLTA & 332 & $2,86 \%$ \\
5 & D1 & 151 & $1,30 \%$ \\
6 & D2 & 133 & $1,14 \%$ \\
7 & D3 & 91 & $0,78 \%$ \\
8 & S1 & 84 & $0,72 \%$ \\
9 & S2 & & \\
10 & S3 & &
\end{tabular}

\section{Sumber : RKP Desa Pasir Eurih Kecamatan Tamansari Kabupaten Bogor Tahun 2017}

Anak-anak sebelum tahun 2000, tidak perlu sekolah apabila sudah dapat membuat pola ataupun sepatu/sandal. Ada pemikiran bahwa tujuan sekolah adalah kerja untuk mencari uang, sedangkan tanpa sekolah pun bila sudah bisa buat sepatu/sandal sudah dapat menghasilkan uang. Biasanya dulu pengrajin memiliki "kenek" yaitu anak-anak yang belajar dari pengrajin tanpa memerlukan waktu yang lama. Dari tahun 2000 hingga sekarang, para anak-anak pengrajin harus sekolah karena masyarakat semakin mengerti bahwa Pendidikan itu penting dan harapannya adalah dapat lebih mengembangkan usaha sepatu dan sandal dengan ilmu yang di dapat. Para pekerja umumnya telah menekuni pekerjaan ini berkisar antara 1 - 30 tahun. Adanya pelatihan dari pemerintah untuk menambah kreatifitas dalam membuat sepatu atau sandal di Desa Pasar Eurih sangat diminati oleh para pengrajin. Seperti pelatihan pemotongan bahan baku dari bahan imitasi ke bahan kulit. Hal ini sangat membantu para pengrajin untuk 
berkreatifitas seiring dengan trend sepatu dan sandal sehingga tidak kalah saing dengan para pengrajin baik dalam maupun luar negeri.

Dalam 1 UMKM membutuhkan idealnya 6 orang tenaga kerja. Terdapat dua jenis pekerjaan dalam pembuatan sepatu dan sandal ini yaitu tukang bawah dan tukang atas. Adapun tugas dari masing-masing tukang adalah sebagai berikut:

Tukang bawah, pada jenis pekerjaan ini tugas tukang bawah adalah melakukan pekerjaan, seperti: membuat permukaan sandal, menggunting, pemberian lem pada bagian sol (bawah sandal), dan memasang pola pada cetakan, serta memanaskan sandal di kompor agar lem merekat kuat dan cepat kering.

Tukang atas, sedangkan pada jenis pekerjaan ini tugas tukang atas adalah menyelesaikan bagian finishing, seperti: menjahit pola dan menyusun sandal dari ukuran terkecil hingga terbesar setelah sandal selesai disusun, barulah dilakukan pengepakan. Sandal tersebut dimasukkan ke dalam kotak kardus.

Tabel 10. Hasil Penilaian Sumber Daya Manusia

\begin{tabular}{|c|c|}
\hline $\begin{array}{l}\text { Indikator Ukuran Penilaian Sumber Daya } \\
\text { Manusia }\end{array}$ & Nilai \\
\hline Pendidikan & 3 \\
\hline Ketrampilan & 4 \\
\hline Kehandalan Berjualan & 4 \\
\hline Nilai rata - rata & 3,6 \\
\hline
\end{tabular}

\section{Sumber : Data Diolah Peneliti}

Tingginya angkatan kerja dipedesaan dibanding perkotaan menggambarkan bahwa potensi angkatan kerja di pedesaan sangat besar, namun potensi angkatan kerja tersebut belum dioptimalkan dengan baik, seiring dengan rendahnya tingkat pendidikan angkatan kerja di pedesaan yang berimbas pada rendahnya ketrampilan yang dimiliki angkatan kerja pedesaan. Disini dibutuhkan peran dari pemerintah daerah, masyarakat dan para pengrajin untuk saling bahu membahu membantu para pemuda setempat.
Dari segi pendanaan, pemerintah daerah diharapkan dapat memberikan fasilitas kredit lunak yang bertujuan untuk memperkuat struktur permodalan UMKM yang belum terlayani oleh perbankan dan lembaga keuangan lainnya.

Di bidang kelembagaan, pemerintah daerah diharapkan dapat memfasilitasi yang diberikan berbentuk program pendaftaran usaha, pengurusan SIUP, TDP, SITU secara gratis. Meskipun tidak selalu gratis, namun dinas memberikan kemudahan dalam pengurusannya. Pemberian fasilitas pengurusan usaha ini 
bertujuan agar UMKM Sepatu dan Sandal lebih memiliki jaminan hukum, terlindungi dari berbagai praktek usaha tidak jujur dan juga kepemilikan berbagai dokumen usaha dapat mempermudah para pengusaha dalam mengakses permodalan di perbankan karena memiliki persyaratan yang dibutuhkan dalam mengakses modal. Pemerintah daerah juga diharapkan memberikan pelatihan mengenai kualitas produk dengan menghadirkan narasumber dari ahli professional Sepatu dan Sandal seperti Yongki Komaladi, dan dari akademisi, pelatihan juga diadakan dengan menggandeng SMESCO sebagai narasumber. Pelatihan yang diberikan berupa pemberian wawasan mengenai manajemen usaha, narasumber dari akademisi berupa pelatihan membuat kas terdiri dari penjualan tunai/non tunai, pengeluaran biaya produksi. Diberikan juga pelatihan mengenai teknik produksi yakni pelatihan pemotongan bahan berbentuk kulit, cara membuat pola dan desain sepatu dan sandal sesuai fashion saat ini.

Pemerintah daerah juga sebaiknya rutin melaksanakan kegiatan expo sebagai sarana untuk mempromosikan produkproduk UMKM Desa Pasir Eurih, pengiriman delegasi pengrajin mengikuti pameran tingkat nasional. Dan menyediakan konsultasi klinik bisnis di koperasi, jika ada pengrajin yang ingin berkonsultasi terutama pemuda yang ingin memulai usahanya.

Adanya kerjasama antara pemerintah daerah, masyarakat dan pengrajin, maka diharapkan pemuda setempat terinspirasi dan memiliki dukungan yang cukup untuk kreatif mengembangkan idenya dalam usaha Sepatu dan Sandal di Desa Pasir Eurih, sehingga usaha sepatu dan sandal ini layak untuk diteruskan.

\section{Analisis Infrastruktur Jalan, Listrik, dan lain-lain}

Kabupaten Bogor merupakan salah satu wilayah yang berbatasan langsung dengan Ibu Kota RI dan secara geografis mempunyai luas sekitar 2.301,95 Km2 terletak antara $6.19^{\circ}-6.47^{\circ}$ lintang selatan dan $106^{\circ} 1^{\prime}-107^{\circ} 103^{\prime}$ bujur timur.

Wilayah ini berbatasan dengan :

Sebelah Utara : Kota Depok

Sebelah Barat : Kabupaten Lebak

Sebelah Barat Daya : Kabupaten Tanggerang

Sebelah Timur : Kabupaten Purwakarta

Sebelah Timur Laut : Kabupaten Bekasi

Sebelah Selatan : Kabupaten Sukabumi

Sebelah Tenggara : Kabupaten Cianjur

Desa Pasir Eurih adalah bagian dari Kecamatan Ciomas Kabupaten Bogor Propinsi Jawa Barat. Namun sekitar Tahun 2001 terbentuklah kecamatan baru yaitu Kecamatan Tamansari yang terdiri atas 8 (delapan) Desa yaitu Desa Sukajadi, Desa 


$\begin{array}{lll}\text { Sukajaya, Desa } & \text { Sukaresmi, Desa } & \text { b. Desa budaya } \\ \text { Sukaluyu, Desa Tamansari, Desa } & \text { c. Desa disekitar obyek wisata/ } \\ \text { Sukamantri, Desa Sirnagalih, dan Desa } & \text { berbasis industry kreatif }\end{array}$

a. Desa wisata/ kampung wisata

Tabel 11. Hasil Penilaian Infrastruktur Jalan, Listrik dan Lain-lain

\begin{tabular}{lc}
\hline \multicolumn{1}{c}{$\begin{array}{c}\text { Indikator Ukuran Infrastruktur Jalan, } \\
\text { Listrik dan Lain-lain }\end{array}$} & Nilai \\
\hline Infrastruktur Jalan & $\mathbf{4}$ \\
Listrik & $\mathbf{4}$ \\
Nilai rata - rata & $\mathbf{4}$ \\
\hline
\end{tabular}

Sumber : Data Diolah Peneliti

Akses jalan dari tempat produksi ke tempat grosir sudah jalan aspal. Sebagian besar bengkel atau tempat produksi para Pengrajin berlokasi di pemukiman pedesaan, sehingga alat transportasi yang diandalkan untuk mengirim barang adalah sepeda motor atau ojek motor, tetapi kendaraan roda empat pun sudah dapat melintas. Fasilitas seperti listrik juga sudah dimanfaatkan para pengrajin di Desa Pasir Eurih untuk mempermudah pekerjaan. Selain untuk penerangan bila bekerja hingga malam, listrik juga digunakan untuk pengeleman, atau yang dikenal dengan istilah lem tembak. Dengan menggunakan lem tembak ini, hasilnya menjadi lebih rapi dan kualitas lem yang diperoleh juga baik. Infrastruktur, dan listrik yang baik maka UMKM sepatu dan sandal Desa Pasir Eurih layak untuk diteruskan.

Adapun summary analisis kelayakan teknis adalah sebagai berikut:

Tabel 12. Summary Analisis Kelayakan Teknis

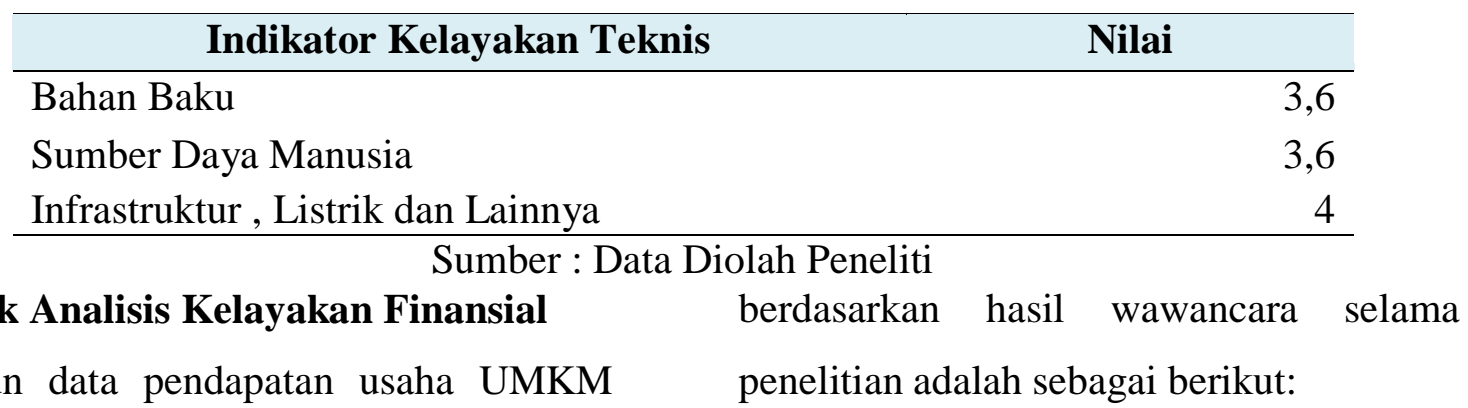

Adapun data pendapatan usaha UMKM penelitian adalah sebagai berikut:

Sepatu dan Sandal Desa Pasir Eurih 
Tabel 13. Pendapatan Usaha UMKM Sepatu dan Sandal Desa Pasir Eurih

\begin{tabular}{clrr}
\hline No & Bulan & $\begin{array}{c}\text { Harga/ } \\
\text { Kodi }\end{array}$ & Penerimaan \\
\hline 1 & Januari & 50 & 40.000 .000 \\
2 & Februari & 50 & 40.000 .000 \\
3 & Maret & 20 & 16.000 .000 \\
4 & April & 50 & 40.000 .000 \\
5 & Mei & 50 & 40.000 .000 \\
6 & Juni & 50 & 40.000 .000 \\
7 & Juli & 50 & 40.000 .000 \\
8 & Agustus & 20 & 16.000 .000 \\
9 & September & 50 & 40.000 .000 \\
10 & Oktober & 20 & 16.000 .000 \\
11 & November & 50 & 40.000 .000 \\
12 & Desember & 50 & 40.000 .000 \\
& Total Penerimaan & $\mathbf{5 1 0}$ & $\mathbf{4 0 8 . 0 0 0 . 0 0 0}$ \\
\hline
\end{tabular}

Sumber : Data Diolah Peneliti

Adapun data pendapatan usaha UMKM Sepatu dan Sandal Desa Pasir Eurih berdasarkan hasil wawancara selama penelitian adalah sebagai berikut:

Tabel 14. Beban Usaha UMKM Sepatu dan Sandal Desa Pasir Eurih

\begin{tabular}{|c|c|c|c|}
\hline No & Bulan & $\begin{array}{c}\text { Harga/ } \\
\text { Kodi }\end{array}$ & Pengeluaran \\
\hline 1 & Januari & 50 & 26.648 .333 \\
\hline 2 & Februari & 50 & 26.648 .333 \\
\hline 3 & Maret & 20 & 10.659 .333 \\
\hline 4 & April & 50 & 26.648 .333 \\
\hline 5 & Mei & 50 & 26.648 .333 \\
\hline 6 & Juni & 50 & 26.648 .333 \\
\hline 7 & Juli & 50 & 26.648 .333 \\
\hline 8 & Agustus & 20 & 10.659 .333 \\
\hline 9 & September & 50 & 26.648 .333 \\
\hline 10 & Oktober & 20 & 10.659 .333 \\
\hline 11 & November & 50 & 26.648 .333 \\
\hline 12 & Desember & 50 & 26.648 .333 \\
\hline \multicolumn{2}{|c|}{ Total Pengeluaran } & 510 & 271.813 .000 \\
\hline \multicolumn{3}{|c|}{ Pendapatan Bersih Per Tahun } & 136.187 .000 \\
\hline
\end{tabular}

Sumber : Data Diolah Peneliti

Dalam kegiatan perusahaan, keuntungan ditentukan dengan cara mengurangkan berbagai biaya yang dikeluarkan dari hasil penjualan yang diperoleh. Biaya yang dikeluarkan meliputi pengeluaran bahan baku (input), pembayaran upah, pembayaran bunga bon putih, biaya penyusutan, biaya transportasi, biaya listrik dan biaya konsumsi. Apabila hasil penjualan yang diperoleh dikurangi dengan biaya-biaya tersebut nilainya positif maka diperoleh keuntungan atau 
pendapatan yang dapat dinikmati oleh para pengrajin atau pengusaha sepatu. Pendapatan bersih yang diperoleh UMKM Sepatu dan Sandal dalam 1 tahun adalah sekitar Rp. $\quad 136.187 .000$ dimana mengindikasikan tingkat keuntungan yang diperoleh cukup tinggi.
Biaya investasi adalah biaya yang harus dikeluarkan sebelum kegiatan usaha dimulai (Tahun ke-0 atau bulan pertama) yaitu sejumlah dana yang dipakai untuk menjalankan usaha. Kegunaan modal untuk usaha UMKM Sepatu dan Sandal Desa Pasir Eurih dapat diuraikan pada Tabel dibawah ini.

Tabel 15. Investasi Usaha UMKM Sepatu dan Sandal Desa Pasir Eurih

\begin{tabular}{|c|c|c|c|c|}
\hline No & Nama Investasi & Satuan & Harga Satuan & Jumlah \\
\hline 1 & Bangunan & 1 & 250.000 .000 & 250.000 .000 \\
\hline 2 & Lahan & & & - \\
\hline 3 & Mesin Jahit & 2 & 1.500 .000 & 3.000 .000 \\
\hline 4 & Mesin Gurinda & 1 & 500.000 & 500.000 \\
\hline 5 & Kayu Pola & 1 & 500.000 & 500.000 \\
\hline 6 & Perlengkapan & & & \\
\hline \multicolumn{4}{|c|}{ Total Investasi } & 254.000 .000 \\
\hline \multicolumn{5}{|l|}{$\begin{array}{l}\text { Asset } \\
\text { Bergerak }\end{array}$} \\
\hline No & Nama Asset & Satuan & Harga Satuan & Jumlah \\
\hline \multirow[t]{2}{*}{1} & Motor & 1 & 12.000 .000 & 12.000 .000 \\
\hline & \multicolumn{2}{|c|}{$\begin{array}{c}\text { Total Investasi Bergerak } \\
\text { Total Investasi }\end{array}$} & & $\begin{array}{r}12.000 .000 \\
266.000 .000 \\
\end{array}$ \\
\hline
\end{tabular}

Sumber : Data Diolah Peneliti

Dari data tabel diatas dapat diinformasikan bahwa investasi yang dibutuhkan untuk memulai usaha sepatu dan sandal adalah Rp. 266.000.000.

Adapun teknik analisa kelayakan finansial UMKM Sepatu dan Sandal Desa Pasir Eurih adalah sebagai berikut:

\section{Payback Period / Payback Method}

Metode payback period merupakan metode penilaian investasi yang sangat sederhana perhitungannya, sehingga banyak digunakan oleh perusahaan Payback Period = Initial Investment $/$ Cash Flow

Payback Period = 266.000.000 / $136.187 .000=2$

Nilai dari payback period penilitian ini adalah 2 dimana artinya diperlukan waktu 2 tahun untuk menutup kembali pengeluaran investasi. 
Tabel 16. Hasil Penilaian Payback Period

\begin{tabular}{cc}
\hline Kriteria & Nilai \\
\hline Payback Period / Payback Method & 5
\end{tabular}

Sumber : Data Diolah Peneliti

Suatu usulan investasi akan disetujui apabila payback period-nya lebih cepat atau lebih pendek dari payback period yang disyaratkan oleh para pengrajin. Meskipun metode payback period memiliki beberapa kelemahan, namun metode ini masih terus digunakan secara intensif dalam membuat keputusan investasi, tetapi metode ini tidak digunakan sebagai alat utama melainkan hanya sebagai indikator dari likuiditas dan risiko investasi. Analisis dengan menggunakan payback period menghasilkan bahwa investasi yang dilakukan dalam usaha sepatu dan sandal di Desa Pasir Eurih layak untuk dilakukan ataupun dilanjutkan karena memberikan manfaat bagi para pengrajin.

\section{Net Present Value}

Keunggulan penggunaan metode Net Present Value (NPV) adalah memperhitungkan nilai waktu dari uang, memperhitungkan arus kas selama usia ekonomis proyek, dan memperhitungkan nilai sisa proyek.

Pada penelitian ini tingkat suku bunga diasumsikan dengan menggunakan nilai $7 \%$ setiap tahunnya selama tiga tahun.

Tabel 17. Perhitungan NPV Usaha UMKM Sepatu dan Sandal Desa Pasir Eurih

\begin{tabular}{ccrc}
\hline Tahun & CIF & DF (7\%) & PV \\
\hline 1 & 136.187 .000 & 1,808 & 246.226 .096 \\
2 & 136.187 .000 & 1,579 & 215.039 .273 \\
3 & 136.187 .000 & 1,379 & 187.801 .873 \\
& Total Present Value & & 649.067 .242 \\
& Investasi Awal & & 266.000 .000 \\
& NPV & & 383.067 .242 \\
\hline
\end{tabular}

Sumber : Data Diolah Peneliti

Tabel 18. Hasil Penilaian Net Present Value

\begin{tabular}{cc}
\hline Kriteria & Nilai \\
\hline Net Present Value & 5 \\
\hline
\end{tabular}

Sumber : Data Diolah Peneliti

Dari hasil penelitian NPV > 0 , Investasi yang dilakukan memberikan manfaat bagi para pengrajin, sehingga usaha UMKM
Sepatu dan Sandal Desa Pasir Eurih layak untuk dijalankan.

Internal Rate of Return 
Internal Rate of Return adalah tingkat diskonto (discount rate) yang menjadikan sama antara present value dari penerimaan cash dan present value dari nilai investasi discount rate/tingkat diskonto yang menunjukkan net present value atau sama besarnya dengan nol.

Pada penelitian ini tingkat suku bunga diasumsikan dengan menggunakan nilai $7 \%$ setiap tahunnya selama tiga tahun.

Tabel 19. Perhitungan IRR Usaha UMKM Sepatu dan Sandal Desa Pasir Eurih

\begin{tabular}{cccccc}
\hline Tahun & \multicolumn{1}{c}{ CIF } & DF (7\%) & PV & $\begin{array}{c}\text { DF } \\
(\mathbf{1 0 \% )})\end{array}$ & PV \\
\hline 1 & $136.187 .000,0$ & 1,808000 & 246.226 .096 & 0,909 & 123.793 .983 \\
2 & $136.187 .000,0$ & 1,579000 & 215.039 .273 & 0,826 & 112.490 .462 \\
3 & $136.187 .000,0$ & 1,379000 & 187.801 .873 & 0,751 & 102.276 .437 \\
Total Present Value & & 649.067 .242 & & 338.560 .882 \\
Investasi Awal & & 266.000 .000 & & 266.000 .000 \\
NPV & & 383.067 .242 & & 72.560 .882 \\
IRR & & & & $11 \%$ \\
\hline
\end{tabular}

Sumber : Data Diolah Peneliti

$$
\begin{aligned}
& \operatorname{IRR}=\mathrm{i}_{1}+\frac{\mathrm{NPV}_{1}}{\mathrm{NPV}_{1}-\mathrm{NPV}_{2}} \times\left(\mathrm{i}_{2}-\mathrm{i}_{1}\right) \\
= & 7 \%+(10 \%-7 \%) \times(383.067 .242 /(383.067 .242-72.560 .882)) \\
= & 11 \%
\end{aligned}
$$

Umumnya pengambilan keputusan sedangkan IRR tidak dapat mengatasi investasi berdasarkan NPV dan IRR akan fenomena tersebut. Meskipun demikian, memberikan hasil yang sama, artinya NPV juga memiliki kelemahan, yaitu NPV "apabila suatu usulan investasi dinilai layak berdasarkan NPV, maka usulan investasi tersebut juga dinilai layak berdasarkan IRR. Namun demikian, menurut kalangan akademisi, NPV dianggap lebih unggul dibandingkan IRR, karena NPV dapat mengatasi fenomena tidak memiliki safety margin (sedangkan IRR memiliki safety margin) dan NPV kalah populer dibandingkan dengan IRR (para investor pada umumnya lebih tertarik menggunakan IRR, karena IRR dapat segera dibandingkan dengan cost of capital).

multiple IRR dan conflict ranking projects,

Tabel 20. Hasil Penilaian Internal Rate of Return

\begin{tabular}{cc}
\hline Kriteria & Nilai \\
\hline Internal Rate of Return & 5 \\
\hline
\end{tabular}

Sumber : Data Diolah Peneliti 
NPV dan IRR sama-sama termasuk kelompok discounted cash flow, penganut nilai waktu dan proceeds selama total usia proyek. Berdasarkan kesamaan demikian, NPV IRR akan memberikan keputusan yang sama dalam menilai usul investasi. Andaikan berbasis NPV usul investasi layak diterima maka demikian pula IRR. NPV dan IRR akan memberikan keputusan yang sama, tetapi sebenarnya terkandung sebuah pengecualian di dalamnya. Pengecualian yang dimaksudkan berkaitan saat menilai salah satu dari dua atau lebih usul investasi bersifat mutually exclusive. Untuk kondisi seperti begitu NPV, IRR dapat bertolak belakang memberikan jawaban secara khusus sering terjadi pada susunan peringkat usul investasi. Hal tersebut, dikarenakan perbedaan asumsi yang melekat terkait tingkat reinvestasi dana bebas. IRR berasumsi dana bebas diinvestasikan kembali dengan tingkat rate of returnnya selama periode sisa usia. Sebaliknya NPV berpegang konsisten besarnya tingkat reinvestasi adalah tetap sebesar tingkat diskonto yang ditetapkan sebelumnya. Namun NPV pada umumnya dipandang unggul ketimbang IRR. Hal ini disebabkan NPV konsisten, yaitu mempertimbangkan perbedaan skala investasi dari pernyataan secara absolut dalam rupiah tidak seperti IRR yang memiliki pernyataan berbentuk persentase sehingga skala investasi terabaikan.

Penelitian ini menunjukan bahwa investasi yang dilakukan dalam usaha kelayakan UMKM Sepatu dan Sandal di Desa Pasie Eurih dapat dikatakan layak karena IRR $(11 \%)>$ I $(7 \%)$.

\section{Average Rate of Return}

Average Rate of Return disebut juga accounting rate of return atau accounting return to investment adalah metode penilaian investasi yang berusaha menunjukkan ratio atau perbandingan antara keuntungan neto tahunan terhadap nilai investasi yang diperlukan untuk memperoleh laba/keuntungan tersebut baik diperhitungkan dengan nilai investasi ( initial investment ) atau rata - rata investasi ( average investment ).

Penelitian ini menggunakan asumsi pertambahan inflasi $8 \%$ setiap tahunnya selama 3 tahun, sehingga di dapatkan ARR sebagai berikut: 
Tabel 21. Perhitungan ARR Usaha UMKM Sepatu dan Sandal Desa Pasir Eurih

\begin{tabular}{crcc}
\hline Periode & \multicolumn{1}{c}{ EAT } & $\begin{array}{c}\text { Investasi } \\
\text { Rata-Rata }\end{array}$ & ARR \\
\hline 1 & 136.187 .000 & & \\
2 & 147.081 .960 & 266.000 .000 & $166 \%$ \\
3 & $158.848 .516,8$ & & \\
Total & $442.117 .476,8$ & 266.000 .000 & \\
\hline
\end{tabular}

Sumber : Sumber : Data Diolah Peneliti

Penelitian ini menunjukan ARR > 100\%.

Tabel 22. Hasil Penilaian Average Rate of Return

\begin{tabular}{cc}
\hline Kriteria & Nilai \\
\hline Average Rate of Return & 5 \\
\hline
\end{tabular}

Sumber : Data Diolah Peneliti

Perhitungan ARR pun menghasilkan bahwa investasi usaha UMKM Sepatu dan Sandal Desa Pasir Eurih dapat diterima dan layak untuk dijalankan.

\section{Profitability Index}

$$
\mathrm{PI}=\frac{\text { PV. Proceed }}{\mathrm{PV} . \text { Outays }}=\frac{136 \cdot 187 \cdot 000}{266 \cdot 000 \cdot 000}=0,5
$$

PV. Outlays

Profitability Index harus lebih besar dari 1 untuk dapat dikatakan layak. Semakin besar nilai PI, maka investasi semakin layak. Dari hasil penelitian, nilai PI adalah 0,5 dimana lebih kecil dari 1. Artinya usaha UMKM Sepatu dan Sandal Desa Pasir Eurih belum memiliki cukup bukti untuk dapat dijalankan dengan menggunakan Profitability Index. Hal ini juga dipengaruhi oleh Profitability Index tidak memberikan informasi mengenai return suatu project, dibutuhkan cost of capital untuk menghitung Profitability
Profitability Index (PI) atau benefit and cost ratio ( $\mathrm{B} \backslash \mathrm{C}$ Ratio) merupakan rasio aktifitas dari jumlah nilai sekarang penerimaan bersih dengan nilai sekarang pengeluaran investasi selama umur investasi. 
global. Perjanjian perdagangan bebas dengan China (CAFTA) pada tahun 2010 memberikan tantangan dan persaingan yang ketat dalam memperebutkan pasar membuat produk sepatu dan sandal harus bersaing dengan produk China. Dari segi harga, produk China lebih murah karena pemerintah China memberi subsidi kepada para pelaku usaha. Oleh karena itu pemerintah daerah diharapkan aktif memberi perlindungan maupun dorongan kepada para pengrajin sepatu dan sandal di Desa Pasir Eurih untuk mampu bersaing.

Tabel 23. Hasil Profitability Index

\begin{tabular}{cc}
\hline Kriteria & Nilai \\
\hline Profitability Index & 1 \\
\hline
\end{tabular}

Sumber : Data Diolah Peneliti

Pemerintah daerah, masyarakat dan pengrajin usaha sepatu dan sandal di Desa Pasir Eurih perlu memberikan perhatian khusus terutama pada bidang promosi usaha. Pemerintah daerah juga sebaiknya rutin melaksanakan kegiatan expo sebagai sarana untuk mempromosikan produkproduk UMKM sepatu dan sandal Desa Pasir Eurih. Pengiriman delegasi pengrajin mengikuti pameran tingkat nasional juga diharapkan akan menambah wawasan dan kreatifitas bersaing pengrajin. Membuat film dokumenter mengenai profil UMKM sepatu dan sandal yang ada di Desa Pasir Eurih, dimana trend dokumentasi ini berguna saat ada kegiatan promosi produk di dalam negeri maupun luar negeri. Di bidang sarana dan prasarana fasilitas yang diberikan berupa bantuan mesin jahit Singer yang besar, mesin press, mesin Emboss, Mesin zigzag, Mesin Oven, Mesin Kun dll. Dengan memanfaatkan teknologi dalam proses produksi, pengrajin diharapkan mampu meningkatkan daya saing serta kualitas barang yang dihasilkan. Pemanfaatan teknologi juga mampu menjangkau pasar yang lebih luas dikarenakan kapasitas produksi yang meningkatkan sehingga mampu menyerap pesanan dari berbagai pihak. Kualitas dan Kuantitas sepatu dan sandal terpenuhi ditambah dengan dorongan promosi yang kuat maka penjualan sepatu dan sandal di Desa Pasir Eurih diharapkan meningkat dan layak untuk dijalankan.

Tabel 24. Summary Hasil Analisis Kelayakan Finansial

\begin{tabular}{lc}
\hline \multicolumn{1}{c}{ Kelayakan Finansial } & Nilai \\
\hline Payback Period & 5 \\
Net Present Value & 5 \\
Internal Rate of Return & 5 \\
\hline
\end{tabular}




\begin{tabular}{lc}
\hline \multicolumn{1}{c}{ Kelayakan Finansial } & Nilai \\
\hline Average Rate of Return & 5 \\
Profitability Index & 1 \\
\hline
\end{tabular}

Sumber : Data Diolah Peneliti

Adapun Summary Hasil Analisis Kelayakan Teknis dan Kelayakan Finansial adalah sebagai berikut:

\section{Tabel 25. Summary Hasil Analisis Kelayakan Teknis dan Kelayakan Finansial}

\begin{tabular}{lc}
\hline \multicolumn{1}{c}{ Kelayakan Finansial } & Nilai \\
\hline Bahan Baku & 3,6 \\
Sumber Daya Manusia & 3,6 \\
Infrastruktur, Listrik dan Lainnya & 4 \\
Payback Period & 5 \\
Net Present Value & 5 \\
Internal Rate of Return & 5 \\
Average Rate of Return & 5 \\
Profitability Index & 1 \\
\hline
\end{tabular}

Sumber : Data Diolah Peneliti

Hasil penelitian menunjukan bahwa dari kelayakan teknis maupun kelayakan finansial, UMKM Sepatu dan Sandal di Desa Pasir Eurih layak untuk di jalankan.

\section{Analisis SWOT (Strength, Weakness,} Opportunity, and Threat).

Analisis ini dilakukan untuk menjawab tujuan dan maksud penelitian tentang strategi pengembangan yang perlu diterapkan untuk meningkatkan kinerja usaha kerajinan sepatu. Analisis SWOT merupakan alat analisis yang dapat digunakan untuk menyusun strategi pengembangan usaha berdasarkan kekuatan, kelemahan, peluang dan ancaman yang dimiliki oleh suatu perusahaan.
Analisis SWOT adalah identifikasi berbagai faktor secara sistematis untuk merumuskan strategi perusahaan. Analisis ini didasarkan pada logika yang dapat memaksimalkan kekuatan (strength) dan peluang (opportunity), namun secara bersamaan dapat meminimalkan kelemahan (weakness) dan ancaman (threats). Proses pengambilan keputusan strategis selalu berkaitan dengan pengembangan misi, tujuan, strategi, dan kebijakan perusahaan. Dengan demikian perencana strategi (strategic planner) harus menganalisis faktor-faktor strategis perusahaan (kekuatan, kelemahan, peluang dan ancaman) dalam kondisi yang ada saat ini.

\section{Faktor Kekuatan}


Faktor kekuatan merupakan faktor internal atau faktor yang berasal dari dalam perusahaan yang mampu mendukung perkembangan perusahaan secara optimal jika potensi yang ada dimaksimalisasikan. Adapun faktor kekuatan yang terdapat di Desa Pasir Eurih dalam memproduksi sepatu dan sandal adalah sebagai berikut:

1. Produk yang dihasilkan unik dan kreatif. Dalam pembuatan sepatu/sandal, pengrajin di Desa Pasir Eurih memiliki pengalaman. Salah satu kunci utama dari produk sepatu/sandal ditentukan oleh model yang unik dan disukai oleh pasar. Para pengrajin di Desa Pasir Eurih cukup kreatif dalam membuat model terbaru. Selain itu, para pengrajin aktif mencari trend terbaru dari model sepatu dan sandal yang sedang diminati di pasaran melalui media internet (online), majalah dan lain-lain. Pengrajin mau belajar menambah ketrampilan yang mendukung produksi seperti melakukan sablon merk sepatu/ sandal sendiri sesuai dengan pesanan. Hal ini mendorong UMKM sepatu dan sandal Desa Pasir Eurih layak dijalankan dan dikembangkan.

2. Harga yang ditawarkan bersaing

Harga yang ditawarkan oleh para pengrajin kepada penjual grosiran cukup terjangkau dan disesuaikan dengan kualitas bahan baku yang digunakan untuk produksi. Sehingga saat ini produksi masih mampu berjalan. Dan disini dibutuhkan kerjasama pemerintah, masyarakat dan pengrajin secara aktif memberi perlindungan maupun dorongan sehingga UMKM sepatu dan sandal Desa Pasir Eurih ini layak dijalankan.

\section{Jadwal Produksi}

Pengrajin sudah dapat melakukan estimasi perhitungan hari produksi, mulai dari pembelian bahan baku sampai dengan pengiriman barang. Sehingga semua pesanan dapat diselesaikan tepat waktu dengan kualitas yang baik. Hal ini dapat menciptakan kepuasan pelanggan dimana dalam penelitian ini adalah penjual grosir. Sehubungan dengan proses produksi yang tepat waktu maka secara proses usaha ini layak untuk dijalankan.

4. Masyarakat yang Ramah

Penduduk di Desa Pasir Eurih sangat ramah terhadap pengunjung yang datang. Pendatang ke Desa Pasir Eurih pasti dapat membuat sepatu/ sandal apabila bergaul dengan para pengrajin. Para pengrajin tidak membatasi apabila ada pengunjung yang mau belajar membuat sepatu dan sandal. Kedatangan pengunjung sangat diterima dengan hangat oleh masyarakat Desa Pasir Eurih. Ini merupakan potensi promosi yang dapat dikembangkan sehingga usaha ini layak untuk dijalankan. 5. Aksesibilitas Bahan Baku.

Kedekatan lokasi dengan pemasok mempengaruhi pada tingkat persediaan bahan baku. Semakin dekat lokasi dengan pemasok akan semakin mudah dalam hal 
persediaan bahan baku. Sehingga diharapkan adanya kebijakan pemerintah daerah mengenai penetapan harga bahan baku dari pemasok yang dapat melindungi pengrajin. Dengan demikian usaha sepatu dan sandal ini layak untuk terus berkembang.

\section{Faktor Kelemahan}

Faktor kelemahan dari UMKM Sepatu dan Sandal di Desa Pasir Eurih adalah sebagai berikut:

\section{Keterbatasan Modal}

Pengrajin di Desa Pasir Eurih hampir 70\% tergantung pada pemilik modal. Pengrajin akan memberikan contoh model sepatu dan sandal yang akan diproduksi, apabila pemilik modal setuju maka bahan baku akan disediakan oleh pemilik modal. Apabila tidak disediakan, maka pemilik modal akan memberikan cek/bon. Cek/bon tersebut hanya boleh digunakan di toko rekanan penyedia bahan baku yang sudah ditunjuk oleh pemilik modal. Pola pemasaran yang dilakukan para Pengrajin cenderung konvensional. Bahkan cenderung dilakukan secara pasif. Mayoritas para Pengrajin menunggu order dari pengusaha atau pedagang sepatusandal. Jika tidak ada order dari para pengusaha tersebut, mereka tidak melakukan produksi. Di sisi lain, potensi pasar masih banyak yang belum digarap dan terbuka luas. Keuntungan dari penjualan produk sepatu-sandal lebih banyak dinikmati oleh para pedagang. Sedangkan para Pengrajin relatif memperoleh keuntungan yang lebih kecil. Penelitian yang dilakukan oleh Putra (2015:7) di Kabupaten Jombang, Dalam hal permodalan, menyediakan perkuatan permodalan dengan mengalokasikan modal bergulir dalam APBD setiap tahun. Pemerintah Daerah menunjuk lembaga perbankan yakni Bank Jombang sebagai pengelola modal bergulir tersebut, sedangkan Dinas Koperasi \& UMKM bertugas membukakan akses maupun pemberian informasi mengenai berbagai bentuk pinjaman yang berasal dari bank. Untuk mengakses permodalan ini, setiap pengusaha harus membuat proposal pengajuan kredit kepada Kepala Dinas Koperasi \& UMKM dengan melampirkan berbagai syarat yang ditetapkan. Proposal ini sebagai acuan dinas untuk melakukan survey usaha yang bersangkutan dan menganalisis informasi yang diperoleh untuk kemudian menjadi dasar dinas dalam menerbitkan surat rekomendasi kelayakan usaha memperoleh modal bergulir. Dengan adanya modal bergulir, pengusaha bisa mengakses permodalan dengan bunga lebih rendah yang sulit didapatkan apabila mengakses di perbankan besar. Dengan dukungan seperti ini diharapkan UMKM sepatu dan sandal layak untuk dijalankan. 
2. Paguyuban koperasi kurang berjalan

Paguyuban koperasi kurang berjalan dikarenakan sudah menjadi kebiasaan para pengrajin apabila membutuhkan modal usaha memintanya kepada pemilik modal. Hal ini sulit dirubah karena sudah menjadi kebiasan yang turun temurun. Rasa persatuan antar pengrajin juga menjadi kurang dikarenakan adanya saingan order yang tinggi dari pemilik modal. Perlunya peran aktif dari Dinas Koperasi dan UMKM melalui kegiatan pengembangan yang diwujudkan dalam berbagai kegiatan seperti pelatihan manajemen usaha, teknik produksi, bantuan sarana dan prasaran serta fasilitasi kelembagaan usaha juga mengacu pada berbagai nomenklatur, dokumen tertulis yakni Undang-Undang No.20 Tahun 2008 bahwa Pemerintah dan Pemerintah Daerah memfasilitasi pengembangan usaha dalam bidang produksi dan pengolahan, pemasaran. Para pengrajin juga diharapkan aktif melaksanakan dialog rutin sesama pengrajin untuk kemudian hasilnya disampaikan kepada pemerintah. Kehadiran diskusi, memberikan sumbangan pemikiran, penerimaan maupun penolakan program yang telah ditawarkan. Melalui kegiatan ini diharapkan UMKM sepatu dan sandal Desa Pasir Eurih layak dijalankan.

3. Administrasi dan Manajemen Keuangan belum teratur
Para pengrajin hanya mengandalkan perhitungan kasar atau tidak menggunakan perhitungan usaha yang baik dalam berproduksi, sehingga tidak jarang biaya operasional yang dikeluarkan selama proses produksi tidak terhitung. Apabila ada orderan Sepatu/Sandal sebesar Rp.10.000.000, maka harus jadi barang Rp.15.000.000. Tetapi ada juga pengrajin yang berpendidikan SMP ke atas sudah memperhitungkan orderan dan biaya yang dikeluarkan dengan output yang dihasilkan. Sistem pencatatan pengrajin belum tertata rapi, sehingga tidak semua pengrajin mengetahui secara pasti berapa rupiah keuntungan yang mereka peroleh selama menjalankan usaha. Selain itu tidak ada pemisahan yang jelas antara pengeluaran pribadi dengan pengeluaran usaha yang menyebabkan usaha sulit berkembang. Paguyuban Desa Pasir Eurih dapat bekerjasama dengan pemerintah daerah dan akademisi untuk memberikan wawasan mengenai manajemen usaha, pelatihan membuat kas yang terdiri dari penjualan tunai/non tunai, pengeluaran biaya produksi, anggaran, pembukuan sederhana, dan banyak pelatihan lainnya. Melalui pelatihan ini diharapkan para pengrajin sudah dapat membuat perencanaan anggaran, mengendalikan biaya produksi, memisahkan biaya produksi dengan pengeluaran rumah tangga, dan mampu membuat pembukuan 
sederhana sehingga usaha ini layak untuk dikembangkan karena memberikan manfaat yang banyak untuk para pengrajin.

4. Manajemen persediaan bahan baku belum teratur

Persediaan bahan baku memegang peranan penting dalam kelancaran proses produksi. Sistem pembelian bahan baku di Desa Pasir Eurih biasanya 1 pengrajin berlangganan di 1 toko saja, apabila ada bahan yang kurang, maka pengrajin harus menunggu sampai bahan tersebut tersedia kembali. Toko langganan penyedia bahan baku merupakan rekanan dari pemilik modal. Hal ini dapat mengganggu proses produksi. Bahan baku Sepatu/Sandal tidak pernah di stock, sehingga para pengrajin harus pintar mengestimasi jumlah bahan baku dengan output yang akan dihasilkan. Menurut para pengrajin Sepatu/Sandal model sepatu cepat berganti sehingga bahan baku tidak perlu di stock karena belum tentu bahan baku tersebut akan digunakan kembali di produksi sepatu/sandal berikutnya. Manajemen bahan baku perlu diterapkan kepada para pengrajin. Hal ini dapat diperoleh dengan bekerjasama dengan akademisi. Diperlukan juga optimalisasi peran aktif koperasi melalui program-programnya dalam penyediaan bahan baku dan modal kerja serta mampu mengkoordinir distribusi produk jadi. sehingga UMKM ini layak untuk dijalankan.

5. Lahan kerja kurang luas dan kurang nyaman

Lahan yang digunakan untuk tempat produksi merupakan rumah tempat seharihari para pengrajin Sepatu/ Sandal tinggal. Tidak ada gudang khusus untuk tempat penyimpanan bahan baku dan sepatu/sandal yang sudah selesai diproduksi, sehingga luas tempat produksi sangat terbatas sekali dan menyebabkan suasana bekerja menjadi kurang nyaman. Dan apabila tidak ada orderan, tenaga kerja yang dipekerjakan oleh para pengrajin tersebut akan tetap tinggal di rumah pengrajin. Ada baiknya ruangan yang dijadikan tempat bekerja untuk pengrajin diperbanyak ventilasi udaranya agar tidak terlalu sesak. Dengan lahan kerja yang nyaman diharapkan pengrajin dapat lebih giat dalam memproduksi sepatu dan sandal sehingga usaha ini layak untuk dijalankan.

\section{Teknologi Minimal}

Teknologi yang digunakan untuk proses produksi sangat minimalis yaitu mesinmesin sederhana, seperti mesin jahit standar dan mesin gurinda. Pengrajin di Desa Pasir Eurih membutuhkan mesin jahit Singer yang besar, mesin press, mesin Emboss, Mesin zigzag, Mesin Oven, Mesin Kun dll. Hal ini dapat meningkatkan jumlah produksi dan 
menjaga kualitas bahan baku pada saat di produksi. Tetapi harga dari mesin tersebut cukup mahal sehingga para pengrajin mengoptimalkan produksi dengan mesin yang ada. Di bidang sarana dan prasarana fasilitas yang dapat diberikan pemerintah dapat berupa bantuan mesin jahit Singer yang besar, mesin press, mesin Emboss, Mesin zigzag, Mesin Oven, Mesin Kun dll. Dengan memanfaatkan teknologi dalam proses produksi, pengrajin diharapkan mampu meningkatkan daya saing serta kualitas barang yang dihasilkan. Pemanfaatan teknologi juga mampu menjangkau pasar yang lebih luas dikarenakan kapasitas produksi yang meningkatkan sehingga mampu menyerap pesanan dari berbagai pihak. Kualitas dan Kuantitas sepatu dan sandal terpenuhi ditambah dengan dorongan promosi yang kuat maka penjualan sepatu dan sandal di Desa Pasir Eurih diharapkan meningkat dan layak untuk dijalankan.

\section{Kurangnya Tenaga Kerja}

Tenaga kerja di Desa Pasir Eurih sulit di dapat. Pemuda setempat sudah jarang yang mau menjadi pengrajin karena begitu lulus sekolah, pemuda setempat lebih memilih bekerja di toko, di pabrik dan lain-lain walaupun tempat tinggalnya masih di Desa Pasir Eurih. Tenaga kerja saat ini diambil dari luar Desa Pasir Eurih, seperti Bandung, Sukabumi, dan daerah lainnya. Kebanyakan tenaga kerja tersebut mendapat informasi dari mulut ke mulut, dan terkadang pengrajin yang main ke daerah-daerah tersebut untuk mencari tenaga kerja yang dibutuhkan. Biasanya setelah tenaga kerja tersebut sudah diajari dan dapat membuat sepatu/ sandal sendiri, tenaga kerja tersebut berhenti bekerja dan membuka usaha sepatu sendiri di daerah asal mereka. Dalam 1 UMKM membutuhkan idealnya 6 orang tenaga kerja, dan para pengrajin sanggup untuk membayar tenaga kerja tersebut, tetapi menjadi kalah produksi karena tenaga kerja tersebut sulit di dapat.

Dari segi pendanaan, pemerintah daerah diharapkan dapat memberikan fasilitas kredit lunak yang bertujuan untuk memperkuat struktur permodalan UMKM yang belum terlayani oleh perbankan dan lembaga keuangan lainnya.

Di bidang kelembagaan, pemerintah daerah diharapkan dapat memfasilitasi yang diberikan berbentuk program pendaftaran usaha, pengurusan SIUP, TDP, SITU secara gratis. Meskipun tidak selalu gratis, namun dinas memberikan kemudahan dalam pengurusannya. Pemberian fasilitas pengurusan usaha ini bertujuan agar UMKM Sepatu dan Sandal lebih memiliki jaminan hukum, terlindungi dari berbagai praktek usaha tidak jujur dan juga kepemilikan berbagai dokumen usaha dapat mempermudah para pengusaha dalam mengakses permodalan di 
perbankan karena memiliki persyaratan yang dibutuhkan dalam mengakses modal. Pemerintah daerah juga diharapkan memberikan pelatihan mengenai kualitas produk dengan menghadirkan narasumber dari ahli professional Sepatu dan Sandal seperti Yongki Komaladi ,dan dari akademisi, pelatihan juga diadakan dengan menggandeng SMESCO sebagai narasumber. Pelatihan yang diberikan berupa pemberian wawasan mengenai manajemen usaha, narasumber dari akademisi berupa pelatihan membuat kas terdiri dari penjualan tunai/non tunai, pengeluaran biaya produksi. Diberikan juga pelatihan mengenai teknik produksi yakni pelatihan pemotongan bahan berbentuk kulit, cara membuat pola dan desain sepatu dan sandal sesuai fashion saat ini.
Pemerintah daerah juga sebaiknya rutin melaksanakan kegiatan expo sebagai sarana untuk mempromosikan produkproduk UMKM Desa Pasir Eurih, pengiriman delegasi pengrajin mengikuti pameran tingkat nasional. Dan menyediakan konsultasi klinik bisnis di koperasi, jika ada pengrajin yang ingin berkonsultasi terutama pemuda yang ingin memulai usahanya.

Adanya kerjasama antara pemerintah daerah, masyarakat dan pengrajin, maka diharapkan pemuda setempat terinspirasi dan memiliki dukungan yang cukup untuk kreatif mengembangkan idenya dalam usaha Sepatu dan Sandal di Desa Pasir Eurih, sehingga usaha sepatu dan sandal ini layak untuk dijalankan.

Tabel 26. Kekuatan dan Kelemahan UMKM Sepatu dan Sandal Desa Pasir Eurih

\begin{tabular}{cll}
\hline No & \multicolumn{1}{c}{ Kekuatan } & \multicolumn{1}{c}{ Kelemahan } \\
\hline 1 & Produk yang dihasilkan unik dan kreatif & Keterbatasan Modal \\
2 & Harga yang ditawarkan bersaing & Paguyuban koperasi kurang berjalan \\
3 & Jadwal Produksi & Administrasi dan Manajemen Keuangan \\
& & belum teratur \\
& & Manajemen persediaan bahan baku belum \\
4 & Masyarakat yang ramah & teratur \\
& & Lahan kerja kurang luas dan kurang nyaman \\
& & Teknologi minimal \\
& & Kurangnya Tenaga Kerja \\
\hline
\end{tabular}

Sumber : Data Diolah Peneliti

\section{Faktor Peluang}

Faktor peluang merupakan faktor eksternal atau berasal dari luar perusahaan yang menjadi kesempatan bagi perusahaan untuk berkembang secara optimal jika mampu memanfaatkannya secara maksimal. Adapun faktor peluang bagi para pengrajin sepatu/sandal di Desa Pasir Eurih adalah sebagai berikut: 
1. Potensi Pengembangan Desa Budaya Kreatif

Desa Wisata Pasir Eurih dicanangkan sebagai desa kreatif budaya di Jawa Barat, bahkan satu-satunya untuk perwakilan Kabupaten Bogor. Disebut Desa Wisata karena autentik dan unik. Disebut autentik salah satunya dari sepatu dan sandalnya, maka disebut sebagai Desa Budaya Kreatif. Desa Pasir Eurih terkenal sebagai desa sentral industri sepatu dan sandal Bogor dan merupakan salah satu daerah pengrajin sepatu dan sandal terbesar di Jawa Barat. Sepatu dan Sandal harus dipikirkan sebagai salah satu komunitas desa wisata Pasir Eurih, dimana Sepatu dan Sandal Desa Pasir Eurih harus dapat dijadikan oleh-oleh khas dari Pasir Eurih. Ada solusi alternatif sebagai sumbang saran untuk perkembangan desa wisata, dimana perkembangan home industri sepatu dan sandal digabungkan dengan desa wisata. Setiap wisatawan biasanya membutuhkan cindera mata untuk di bawa pulang ke daerah asalnya. Atraksinya adalah membuat Sepatu dan Sandal, sehingga ketika pengunjung atau wisatawan pulang dari Pasir Eurih harus sudah dapat oleh-oleh Sepatu dan Sandal yang dibuat oleh wisatawan sendiri. Desa Pasir Eurih juga merupakan tempat dilaksanakannya Jambore Wisata yaitu tanggal 28 Agustus 2017. Ini merupakan salah satu peluang yang besar dan baik untuk perkembangan UMKM Sepatu dan Sandal di Desa Pasir Eurih. Hal ini merupakan salah satu peluang yang sangat baik bagi pengembangan sepatu dan sandal di Desa Pasir Eurih sehingga usaha ini layak di jalankan.

2. Produk sudah dikenal masyarakat

Keunggulan produk yang dihasilkan oleh UMKM Sepatu/Sandal Desa Pasir Eurih sudah dikenal oleh masyarakat luas. Hal tersebut berimbas pada hasil produksi dimana tak jarang banyak pembeli yang datang dari luar kota Bogor yaitu Jabodetabek, Medan dan Pekanbaru. Bahkan ada hotel yang memperbolehkan para pengrajin untuk membuka stand penjualan Sepatu dan Sandal setiap hari Sabtu dan Minggu. Pemerintah daerah juga diharapkan membantu dalam pengurusan HAKI, karena biaya pengurusan HAKI tidak murah, dinas juga mempermudah birokrasi dengan membantu pengurusan HAKI karena HAKI merupakan kewenangan Kementerian Hukum dan HAM sehingga dinas maupun pemda tidak berwenang untuk menerbitkan HAKI. Pihak pengrajin hanya menyetorkan syarat-syarat yang diperlukan untuk kemudian selanjutnya di urus oleh Dinas Koperasi \& UMKM. Pemberian HAKI penting untuk mendorong daya saing dengan produk lain yang sejenis, selain sebagai akses perlindungan hukum atas produk yang 
dimilikinya. Dinas Koperasi \& UMKM juga aktif memberi sosialisasi tentang pentingnya kepemilikan atas HAKI. Contoh yang paling sederhana adalah Cibaduyut merupakan salah satu daerah yang belajar dari Desa Pasir Eurih. Tetapi nama Cibaduyut lebih besar dan maju dalam produksi sepatu dan sandal. Dengan bantuan pengurusan HAKI ini diharapkan usaha sepatu dan sandal Desa Pasir Eurih lebih dikenal masyarakat luas sehingga layak untuk dijalankan.

\section{Dukungan dari Pemerintah}

Adanya pelatihan dari pemerintah untuk menambah kreatifitas dalam membuat sepatu atau sandal di Desa Pasar Eurih sangat diminati oleh para pengrajin. Seperti pelatihan pemotongan bahan baku dari bahan imitasi ke bahan kulit. Hal ini sangat membantu para pengrajin untuk berkreatifitas seiring dengan trend sepatu dan sandal sehingga tidak kalah saing dengan para pengrajin baik dalam maupun luar negeri. Selain menerima pelatihan, para pengrajin Desa Pasir Eurih juga memberi pelatihan, saling berbagi ilmu dan pengalaman ke daerah lainnya. Ketua Paguyuban Pasir Eurih pernah membawa 6 orang para pengrajin ke Bangka Belitung untuk memberikan pelatihan pembuatan sandal dan sepatu. Sikap terbuka untuk belajar dan mau berbagi ilmu dan pengalaman inilah yang merupakan peluang besar bagi perkembangan usaha
Sepatu dan Sandal untuk lebih berkembang lagi.

4. Tempat Penjualan Strategis

Tempat penjualan sangat penting dalam memasarkan suatu produk. Jika tempat penjualan semakin strategis, maka akan mudah memasuki pasar. Desa Pasir Eurih terkenal sebagai desa sentral industri sepatu dan sandal Bogor dan merupakan salah satu daerah pengrajin sepatu dan sandal terbesar di Jawa Barat. Banyak department store dan pusat grosir sepatu dan sandal yang dijadikan sebagai sentra penjualan kerajinan sepatu/sandal dari Desa Pasir Eurih, sehingga mempermudah konsumen yang ingin membeli sepatu.

\section{Potensi Diversifikasi Produk}

Para pengrajin sudah mulai memikirkan cara pengolahan sisa dari produksi bahan baku seperti pembuatan gantungan kunci khas Desa Pasir Eurih dan aksesoris lainnya. Kreatifitas ini baik untuk terus dikembangkan.

\section{Faktor Ancaman}

Adapun faktor ancaman yang bersifat eksternal bagi perkembangan UMKM Sepatu dan Sandal di Desa Pasir Eurih adalah sebagai berikut:

1. Pesaing dari dalam dan luar negeri

Pesaing pengrajin sepatu dan sandal di Desa Pasir Eurih terdapat di beberapa tempat di Indonesia seperti para pengrajin sepatu di Bandung yang terkenal dengan 
sepatu Cibaduyut-nya dan di daerah Sukabumi. Cibaduyut merupakan salah satu daerah yang belajar dari Desa Pasir Eurih. Tetapi nama Cibaduyut jauh lebih besar dan maju daripada Desa Pasir Eurih. Pesaing utama UMKM Sepatu dan Sandal Desa Pasir Eurih adalah produk-produk sepatu dari luar negeri yang sudah menggunakan teknologi yang canggih sehingga dapat menghasilkan kualitas yang baik dan harga yang murah, seperti produk sepatu dari China yang harganya dapat lebih murah dengan kualitas yang cukup baik. Diberlakukannya perjanjian perdagangan bebas negara lain menuntut UMKM untuk terus berkembang dan memiliki daya saing tinggi. Maka dari itu pemerintah daerah melalui Dinas Koperasi \& UMKM diharapkan berupaya semaksimal mungkin mempersiapkan UMKM Sepatu dan Sandal untuk bersaing dengan produk global. Perjanjian perdagangan bebas dengan China (CAFTA) pada tahun 2010 memberikan tantangan dan persaingan yang ketat dalam memperebutkan pasar membuat produk sepatu dan sandal harus bersaing dengan produk China. Dari segi harga, produk China lebih murah karena pemerintah China memberi subsidi kepada para pelaku usaha. Oleh karena itu pemerintah daerah diharapkan aktif memberi perlindungan maupun dorongan kepada para pengrajin sepatu dan sandal di Desa Pasir Eurih untuk mampu bersaing. Pemerintah dapat membantu Pengrajin Sepatu Sandal dengan membatasi impor sepatu. Pemerintah juga dapat membantu UMKM Sepatu dan Sandal dengan memfasilitasi jalur distribusi yang baru. Optimalisasi jaringan/saluran Pemasaran ini diharapkan dapat memperluas jaringan relasi pemasaran sehingga usaha sepatu dan sandal Desa Pasir Eurih layak dijalankan.

\section{Siklus Penjualan}

Perputaran sepatu/sandal ini biasanya 9 bulan, sepi orderan 3 bulan tapi tidak beruntun. Pesanan usaha sepatu biasanya ramai hanya pada waktu-waktu tertentu. Misalnya saat Lebaran, Natal, menjelang perayaan tahun baru dan hari-hari besar lainnya sedangkan pada bulan-bulan biasa pesanan sepatu sangat minim sekali. Pemerintah dapat memfasilitasi promosi produk pada masa-masa penjualan tidak ramai dengan mengadakan event pameran atau yang sejenisnya. Optimalisasi Koperasi yang telah dibentuk juga diperlukan sehingga mampu menyediakan bahan baku dan modal kerja serta mampu mengkoordinir distribusi produk jadi sehingga usaha sepatu dan sandal ini layak dijalankan.

\section{Daya Beli Masyarakat}

Penurunan daya beli masyarakat diakibatkan oleh beberapa faktor dimana salah satunya kenaikan inflasi. Faktor berpengaruh berikutnya adalah kenaikan 
pada biaya bahan baku yang mempertinggi

biaya produksi. Kreatifitas dalam membuat model sepatu sandal ditingkatkan, sehingga semakin beraneka ragam bentuk dan modelnya dengan kualitas yang semakin baik. Sehingga diharapkan pangsa pasar menjadi lebih luas, tidak hanya dalam negeri tetapi juga luar negeri.

Tabel 27. Peluang dan Ancaman UMKM Sepatu dan Sandal Desa Pasir Eurih

\begin{tabular}{cll}
\hline No & \multicolumn{1}{c}{ Peluang } & \multicolumn{1}{c}{ Ancaman } \\
\hline 1 & Desa Budaya Kreatif & Pesaing dari dalam dan luar negeri \\
2 & Produk sudah dikenal masyarakat & Musim \\
3 & Lokasi dekat dengan pemasok. & Daya Beli Masyarakat \\
4 & Pelatihan & \\
5 & Tempat Penjualan Strategis & \\
6 & Kreatifitas & \\
\hline
\end{tabular}

Sumber : Data Diolah Peneliti

\section{Strategi Pengembangan Usaha Pengrajin Sepatu Berdasarkan Analisis SWOT}

Dengan melihat faktor kekuatan, kelemahan, peluang dan ancaman pada bisnis Pengrajin UMKM Sepatu Sandal Desa Pasir Eurih Bogor, dapat dirumuskan beberapa strategi pengembangan usaha tersebut.

Tabel 28. Matriks Strategi Analisis Kelayakan UMKM Sepatu dan Sandal Analisis SWOT

\begin{tabular}{|c|c|c|}
\hline Faktor & Strategi Strength & Strategi Weekness \\
\hline \multirow{10}{*}{$\begin{array}{l}\text { Faktor } \\
\text { Internal }\end{array}$} & Kekuatan (S) & Kelemahan (W) \\
\hline & Produk yang dihasilkan unik dan kreatif & Keterbatasan Modal, \\
\hline & Harga yang ditawarkan bersaing & Paguyuban Koperasi Kurang Berjalan \\
\hline & Jadwal Produksi & Administrasi dan Manajemen Keuangan \\
\hline & Masvarakat vano ramah & Manajemen persediaan bahan baku \\
\hline & & belum teratur \\
\hline & Aksesibilitas Bahan Baku & Lahan Kerja Kurang Luas dan Kurang \\
\hline & & Nyaman \\
\hline & & Teknologi Minimal \\
\hline & & Kurangnya Tenaga Kerja \\
\hline Kesempatan & STRATEGI SO & STRATEGI WO \\
\hline Potensi Desa & Terdapat potensi desa budaya kreatif & Pemerintah daerah diharapkan dapat \\
\hline Budaya & yang sangat membutuhkan kreatifitas & memberikan fasilitas kredit lunak yang \\
\hline Kreatif & masyarakat lokal untuk menjual produk & bertujuan untuk memperkuat struktur \\
\hline & khas dari daerah mereka. Desa Pasir & permodalan UMKM yang belum \\
\hline & Eurih sendiri, secara internal telah & terlayani oleh perbankan dan lembaga \\
\hline & memiliki kompetensi yang baik dalam & keuangan lainnya. \\
\hline & $\begin{array}{l}\text { hal produksi sepatu dan sandal. Selain } \\
\text { itu Desa Pasir Eurih juga memiliki }\end{array}$ & $\begin{array}{l}\text { Dengan demikian, para pengrajin dapat } \\
\text { mandiri dan menialankan pengambilan }\end{array}$ \\
\hline & kreatifitas dan proses produksi yang & keputusan bisnis lebih baik. Selama ini \\
\hline & telah cukup lama beroperasi. Oleh & dalam prakteknya, keputusan bisnis \\
\hline & $\begin{array}{l}\text { karena itu, potensi ini harus digarap dan } \\
\text { ditingkatkan. }\end{array}$ & masih tergantung dari pemilik modal. \\
\hline
\end{tabular}




\begin{tabular}{|c|c|c|}
\hline Faktor & Strategi Strength & Strategi Weekness \\
\hline $\begin{array}{l}\text { Produk sudah } \\
\text { dikenal } \\
\text { masyarakat }\end{array}$ & $\begin{array}{l}\text { Dengan adanya Desa Budaya Kreatif } \\
\text { dapat dimanfaatkan sebagai salah satu } \\
\text { fasilitas untuk lebih memperkenalkan } \\
\text { produk Sepatu dan Sandal Desa Pasir } \\
\text { Eurih ke masyarakat yang lebih luas. } \\
\text { Desa Pasir Eurih telah memiliki pasar } \\
\text { dari pengrajin sepatu dan sandal dari } \\
\text { Bogor. Menurut peneliti, kesempatan } \\
\text { lebih besar harusnya sudah terbuka. } \\
\text { Sasaran selanjutnya adalah menjual } \\
\text { sepatu dan sandal ini lebih luas. }\end{array}$ & $\begin{array}{l}\text { Pemerintah memberi bantuan } \\
\text { pengembangan teknologi produksi } \\
\text { dengan cara memberi bantuan seperti } \\
\text { mesin jahit Singer yang besar, mesin } \\
\text { press, mesin Emboss, Mesin zigzag, } \\
\text { Mesin Oven, Mesin Kun dll. Dengan } \\
\text { memanfaatkan teknologi dalam proses } \\
\text { produksi, mampu meningkatkan daya } \\
\text { saing serta kualitas barang yang } \\
\text { dihasilkan. Pemanfaatan teknologi juga } \\
\text { mampu menjangkau pasar yang lebih luas } \\
\text { dikarenakan kapasitas produksi yang } \\
\text { meningkatkan sehingga mampu } \\
\text { menyerap pesanan dari berbagai pihak. }\end{array}$ \\
\hline $\begin{array}{l}\text { Dukungan } \\
\text { dari } \\
\text { Pemerintah }\end{array}$ & & $\begin{array}{l}\text { Optimalisasi Koperasi yang telah } \\
\text { dibentuk sehingga mampu menyediakan } \\
\text { bahan baku dan modal kerja serta mampu } \\
\text { mengkoordinir distribusi produk jadi } \\
\text { Hendaknya koperasi menjadi badan } \\
\text { usaha bagi pengrajin sepatu dan sandal di } \\
\text { Desa Pasir Eurih. }\end{array}$ \\
\hline \multicolumn{3}{|l|}{$\begin{array}{l}\text { Tempat } \\
\text { penjualan } \\
\text { strategis } \\
\text { Potensi } \\
\text { Diversifikasi } \\
\text { Produk }\end{array}$} \\
\hline Ancaman & Strategi ST & Strategi WT \\
\hline $\begin{array}{l}\text { Pesaing dari } \\
\text { dalam dan } \\
\text { luar negeri }\end{array}$ & $\begin{array}{l}\text { Strategi dari pemerintah untuk } \\
\text { mengatasi pesaing dari luar adalah } \\
\text { pembatasan import (kuota dan tarif) dan } \\
\text { mengkaji produk import, mempelajari } \\
\text { proses produksi dan teknologi produk } \\
\text { luar negeri, juga melatih penduduk lokal } \\
\text { sehingga kompetensi penduduk lokal } \\
\text { bisa naik. }\end{array}$ & $\begin{array}{l}\text { Pemerintah Daerah memberikan fasilitas } \\
\text { kredit lunak yang bertujuan untuk } \\
\text { memperkuat struktur permodalan UMKM } \\
\text { yang belum terlayani oleh perbankan dan } \\
\text { lembaga keuangan lainnya }\end{array}$ \\
\hline $\begin{array}{l}\text { Siklus } \\
\text { Penjualan }\end{array}$ & $\begin{array}{l}\text { Pemanfaatan teknologi untuk } \\
\text { penyebaran informasi dan media } \\
\text { promosi sepatu dan sandal Desa Pasir } \\
\text { Eurih.Trend dokumentasi ini berguna } \\
\text { saat ada kegiatan promosi produk di } \\
\text { dalam negeri maupun luar negeri. }\end{array}$ & $\begin{array}{l}\text { Optimalisasi jaringan / saluran } \\
\text { Pemasaran. Memperluas jaringan relasi } \\
\text { pemasaran dengan bekerjasama dengan } \\
\text { Pemerintah, dapat membantu UMKM } \\
\text { Sepatu dan Sandal dengan memfasilitasi } \\
\text { jalur distribusi yang baru. } \\
\text { Pemanfaatan website atau email sebagai } \\
\text { sarana promosi dan pemasaran }\end{array}$ \\
\hline $\begin{array}{l}\text { Daya beli } \\
\text { masyarakat }\end{array}$ & $\begin{array}{l}\text { Pemerintah memfasilitasi Promosi } \\
\text { produk pada masa penjualan yang sepi } \\
\text { dengan adanya pameran di wilayah } \\
\text { Tangerang dan Jakarta. }\end{array}$ & \\
\hline
\end{tabular}

Sumber : Data Diolah Peneliti 


\section{KESIMPULAN}

Berdasarkan hasil penelitian mengenai analisis kinerja dan strategi pengembangan usaha kerajinan sepatu dan sandal di Desa Pasir Eurih, maka dapat disimpulkan :

1. Hasil penilaian analisis deskriptif melalui indicator trend produksi, potensi pemasaran, perkembangan penduduk dan pendapatan per kapita masyarakat menunjukan bahwa UMKM sepatu dan sandal Desa Pasir Eurih layak untuk dijalankan. Hasil penilaian analisis kelayakan teknis melalui indikator bahan baku, sumber daya manusia, infrastruktur, listrik dan lainnya menunjukan bahwa UMKM sepatu dan sandal Desa Pasir Eurih layak untuk dijalankan. Hasil penilaian analisis kelayakan finansial melalui payback period, net present value, internal rate of return dan average rate of return menunjukan bahwa UMKM sepatu dan sandal Desa Pasir Eurih juga layak untuk dijalankan. Hanya penilaian dengan profitability index yang belum memiliki bukti yang cukup untuk menunjukan kelayakan UMKM sepatu dan sandal di Desa Pasir Eurih.

2. Adapun faktor internal yang menjadi faktor kekuatan para pengrajin UMKM sepatu sandal desa pasir eurih adalah produk yang dihasilkan unik dan kreatif, harga yang ditawarkan bersaing, pengrajin sudah dapat mengestimasi jadwal produksi sesuai pesanan, dan sikap masyarakat desa pasir eurih yang ramah. Sedangkan yang menjadi kelemahannya adalah keterbatasan modal, paguyuban koperasi kurang berjalan, administrasi dan manajemen keuangan belum teratur, manajemen persediaan bahan baku belum teratur, lahan kerja kurang luas dan kurang nyaman, teknologi minimal, kurangnya tenaga kerja. Faktor eksternal yang menjadi kekuatan UMKM sepatu dan sandal Desa Pasir Eurih adalah adanya potensi pengembangan desa wisata dan dicanangkan sebagai desa budaya kreatif, produk sepatu dan sandal sudah dikenal masyarakat, adanya dukungan dari pemerintah melalui pelatihan menambah kreatifitas pengrajin, tempat penjualan strategis dan semangat kreatifitas pengrajin memberikan potensi diversifikasi produk dalam mengembangkan usaha mengikuti trend sepatu dan sandal. Kelemahannya adalah Sarana transportasi terbatas, pesaing dari dalam dan luar negeri yang semakin banyak, musim, dan daya beli masyarakat. 
3. Berdasarkan analisis SWOT maka strategi yang dapat dijalankan oleh para pengrajin dalam rangka mengembangkan usaha UMKM sepatu dan sandal Desa Pasir Eurih adalah peningkatan kreatifitas dalam membuat model sepatu sandal, sehingga semakin beraneka ragam bentuk dan modelnya, optimalisasi jaringan / saluran pemasaran melalui pembangunan kerjasama dengan sesama pengrajin atau pengusaha dan pemasar lainnya, memperluas jaringan relasi pemasaran, pemanfaatan website atau email sebagai sarana promosi dan pemasaran (pengembangan ecommerce), mengalokasikan dana dari hasil penjualan untuk meningkatkan teknologi produksi yang dipergunakan, bekerjasama dalam rangka optimalisasi koperasi yang telah dibentuk sehingga mampu menyediakan bahan baku dan modal kerja serta mampu mengkoordinir distribusi produk jadi, para pengrajin bekerjasama untuk membangun kekuatan bersama sehingga bisa saling menutupi atau mengeliminir kelemahan.

Strategi yang dapat dijalankan oleh pemerintah dalam rangka mengembangkan usaha UMKM sepatu dan sandal Desa Pasir Eurih adalah pemerintah dapat membantu pengrajin sepatu sandal dengan memfasilitasi jalur distribusi yang baru, pemerintah memfasilitasi para pengrajin dengan mengadakan pelatihan tentang manajemen keuangan, manajemen bisnis dan manajemen persediaan, pemerintah memberi bantuan pengembangan teknologi produksi, pemerintah dapat membantu pengrajin sepatu sandal dengan membatasi impor sepatu, pemerintah memfasilitasi promosi produk pada masa-masa penjualan tidak ramai dengan mengadakan event pameran atau yang sejenisnya, pemerintah mengeluarkan regulasi dan kebijakan yang mendukung peningkatan dan pengembangan produksi para pengrajin.

\section{Saran}

Adapun saran yang bisa disampaikan untuk berbagai pihak agar pengembangan usaha para Pengrajin Sepatu Sandal di Kecamatan Ciomas Kabupaten Bogor adalah sebagai berikut:

1. Koperasi

Badan usaha koperasi harus aktif. Lembaga pemerintah harus aktif dalam control dan pengembangan koperasi tersebut. Dengan demikian masalah permodalan dan manajerial dapat terselesaikan

\section{Planning}

Membuat roadmap dan sasaran dari produk Desa Pasir Eurih. Sejauh ini 
potensi pasar lokal dan sekitar telah tergarap dengan baik. Akan tetapi karena permodalan dan manajerial, produk tidak dapat berkembang atau dijual di luar daerah jangkauan. Oleh sebab itu butuh badan usaha (koperasi) dan roadmap untuk pengembangan produk.

\section{Eksekusi}

Menjalankan roadmap dan proses trial $\&$ error. Dokumentasi (pencatatan masalah dan rekap keuangan) harus mulai di lakukan dengan baik, selanjutnya adalah evaluasi dari capaian strategi koperasi.

\section{DAFTAR PUSTAKA}

Bambang Riyanto, 1995, Dasar-dasar Pembelanjaan Perusahaan, Edisi Keempat , BPFE UGM , Yogyakarta.

Husain Umar, 1997, Studi Kelayakan Bisnis : Manajemen, Metode dan Kasus, Gramedia Pustaka Utama , Jakarta.

Husnan, Suad dan Suwarsono, 1995, Studi Kelayakan Proyek UPP, AM YKN, Yogyakarta.

Kasmir dan Jakfar. 2003. Studi Kelayakan Bisnis. Kencana, Jakarta.
Kusmayadi \& Endar Sugiarto. 2000. Metodologi Penelitian Dalam Biᄀdang Kepariwisataan.Jakarta.

Mubyarto, 2003, Mengembangkan ekonomi rakyat sebagai landasan ekonomi pancasila, Jurnal Ekonomi Rakyat [artikel - th. Ii no. 8 - nopember 2003]

Partomo, T. dan A. Soejono. 2004. Ekonomi Skala Kecil/Menengah dan Koperasi. Ghalia, Jakarta.

Pearce dan Robinson. 1997. Manajemen Strategik. Terjemahan. Bina Rupa Aksara, Jakarta.

Radar Bogor. 2008. "Usaha Kecil Sepatu makin Menggeliat di Bogor". Radar Bogor: 5

Rangkuti, F. 2006. Analisis SWOT Teknik Membedah Kasus Bisnis. PT. Gramedia Pustaka Utama, Jakarta.

Supranto, J. 2001. Pengukuran Tingkat Kepuasan Pelanggan: Untuk Menaikkan Pangsa Pasar. Cetakan Kedua.Jakarta

Weston, J. Fred, and Bringham, Eugene. F, 1994, Dasar-dasar Manajemen Keuangan, Edisi Ketujuh, Erlangga, Jakarta.

Yacob, Ibrahim, 1997, Studi Kelayakan Bisnis, Rineka Cipta, Jakarta 